\title{
Mesenchymal stromal cell therapies: immunomodulatory properties and clinical progress
}

\author{
Xiaomo $\mathrm{Wu}^{1,2}$, Ju Jiang ${ }^{1}$, Zhongkai Gu${ }^{3}$, Jinyan Zhang ${ }^{1}$, Yang Chen ${ }^{1 *}$ and Xiaolong Liu ${ }^{4 *}$ (D)
}

\begin{abstract}
Mesenchymal stromal cells (MSCs) are a subset of heterogeneous non-hematopoietic fibroblast-like cells that can differentiate into cells of multiple lineages, such as chondrocytes, osteoblasts, adipocytes, myoblasts, and others. These multipotent MSCs can be found in nearly all tissues but mostly located in perivascular niches, playing a significant role in tissue repair and regeneration. Additionally, MSCs interact with immune cells both in innate and adaptive immune systems, modulating immune responses and enabling immunosuppression and tolerance induction. Understanding the biology of MSCs and their roles in clinical treatment is crucial for developing MSCbased cellular therapy for a variety of pathological conditions. Here, we review the progress in the study on the mechanisms underlying the immunomodulatory and regenerative effects of MSCs; update the medical translation of MSCs, focusing on the registration trials leading to regulatory approvals; and discuss how to improve therapeutic efficacy and safety of MSC applications for future.
\end{abstract}

Keywords: MSCs, Immunomodulatory activity, Paracrine effects, Cellular therapy

\section{Introduction}

Prior to being coined as mesenchymal stem cells by Caplan [1], mouse marrow-derived fibroblasts were exploited as feeder cells for long-term culture of hematopoietic stem cells, and Friedenstein et al. found, apart from niche-like properties, these cells are capable of generating bone/reticular tissue, cartilage, and fat [2-6]. Subsequently Pittenger et al. established that human bone marrow (BM) also contains a subpopulation of stromal cells exhibiting trilineage mesenchymal potential, differentiating into adipocytes, chondroblasts, and osteoblasts under defined condition in vitro [7]. Since then, these multipotent stromal cells have been isolated from a variety

\footnotetext{
*Correspondence: cyfuzhou2008@126.com; xiaoloong.liu@gmail.com 'Dermatology Institute of Fuzhou, Dermatology Hospital of Fuzhou, Xihong Road 243, Fuzhou 350025, China

${ }^{4}$ The United Innovation of Mengchao Hepatobiliary Technology Key Laboratory of Fujian Province, Mengchao Hepatobiliary Hospital of Fujian Medical University, Xihong Road 312, Fuzhou 350025, China

Full list of author information is available at the end of the article
}

of tissues other than BM, including skeletal muscle, adipose tissue (AT), dental pulp, tendon, Wharton's jelly, umbilical cords, amniotic fluid, and placentae, literately nearly all tissues but essentially from perivascular fraction [8]. Notably, the MSCs acronym has been collectively referred to as mesenchymal stem cells, multipotential stromal cells and mesenchymal stromal cells.

At present, identifying and characterizing MSCs are mostly via in vitro work based on the ability of adhering to plastic culture dishes and the capability of consecutive expansion; culture-expanded MSCs unavoidably consist of heterogeneous population of cells with differentially committed progenitors, whereas the degree of heterogeneity varies depending on the isolation technique, culturing protocols and media used, passage number as well as tissue origin [9-13]. In 2005, the International Society for Cellular Therapy (ISCT) issued a position statement for the nomenclature of mesenchymal stromal cells (MSCs) [14-16], clarifying that the term mesenchymal stem cell is 
not equivalent or interchangeable with MSC (mesenchymal stromal cell) as well as defining MSC when meeting minimal criteria; these include being plastic adherent; having trilineage differentiation potential (osteogenic, adipogenic, and chondrogenic); cell-surface expressing of CD90, CD105, and CD73 (positive, > 95\%); and lacking cell surface antigens CD45, CD34, CD14 or CD11b, CD79 $\alpha$ or CD19, and HLA-DR (negative, <2\%). Subsequently, the discovery that perivascular cells meeting the ISCT MSC minimal criteria led to a recent important paradigm shift in our understanding of in vivo identity of MSCs being perivascular pericytes $[17,18]$, which markedly diversifying the study and application of MSCs. Previously, investigational new cellular therapeutics were almost exclusively derived from BM [19]; however, in the past decade, approximately half of the new MSC products applied in clinical trials have been obtained from tissues other than BM, typically enriched with vascular structure [13].

Pioneering translational studies on the exploitation of the stem/progenitor properties of MSCs nonetheless revealed MSCs have the capacity to dampen inflammatory response, affecting the functionality of both adaptive and innate immune systems [11, 20-22]. MSCs produce extracellular vesicles (EVs), including exosomes and microvesicles, and a multitude of cytokines and growth factors capable of suppressing immune responses by inhibiting $\mathrm{B}$ and $\mathrm{T}$ cell proliferation, preventing monocyte differentiation and dendritic cells (DCs) maturation, meanwhile promoting generation of regulatory $\mathrm{T}$ cells, regulatory B cells, and M2 macrophages [23-25]. Such insight led to first clinical trials, which found transfusion of MSCs contributed to accelerating hematopoietic recovery following high-dose myeloablative chemotherapy and reversing steroid-resistant graft versus host disease (GvHD) [26], and actual current clinical value of MSCs is primarily derived from immunomodulatory properties (demonstrated in Fig. 1), [11, 27, 28]. Since the first clinical trial using MSCs as cellular pharmaceutical agents, numerous clinical trials have been conducted to test the efficacy of MSC-based therapy and over 10,000 of patients have been administered with allogeneic or autologous MSCs for the treatment of various diseases [21, 29] (Mesenchymal stem cells search at www.clinicaltrials. gov, accessed on 24 April 2020), including GvHD, myocardial infarction (MI), stroke, Crohn's disease, multiple sclerosis (MS), amyotrophic lateral sclerosis (ALS),

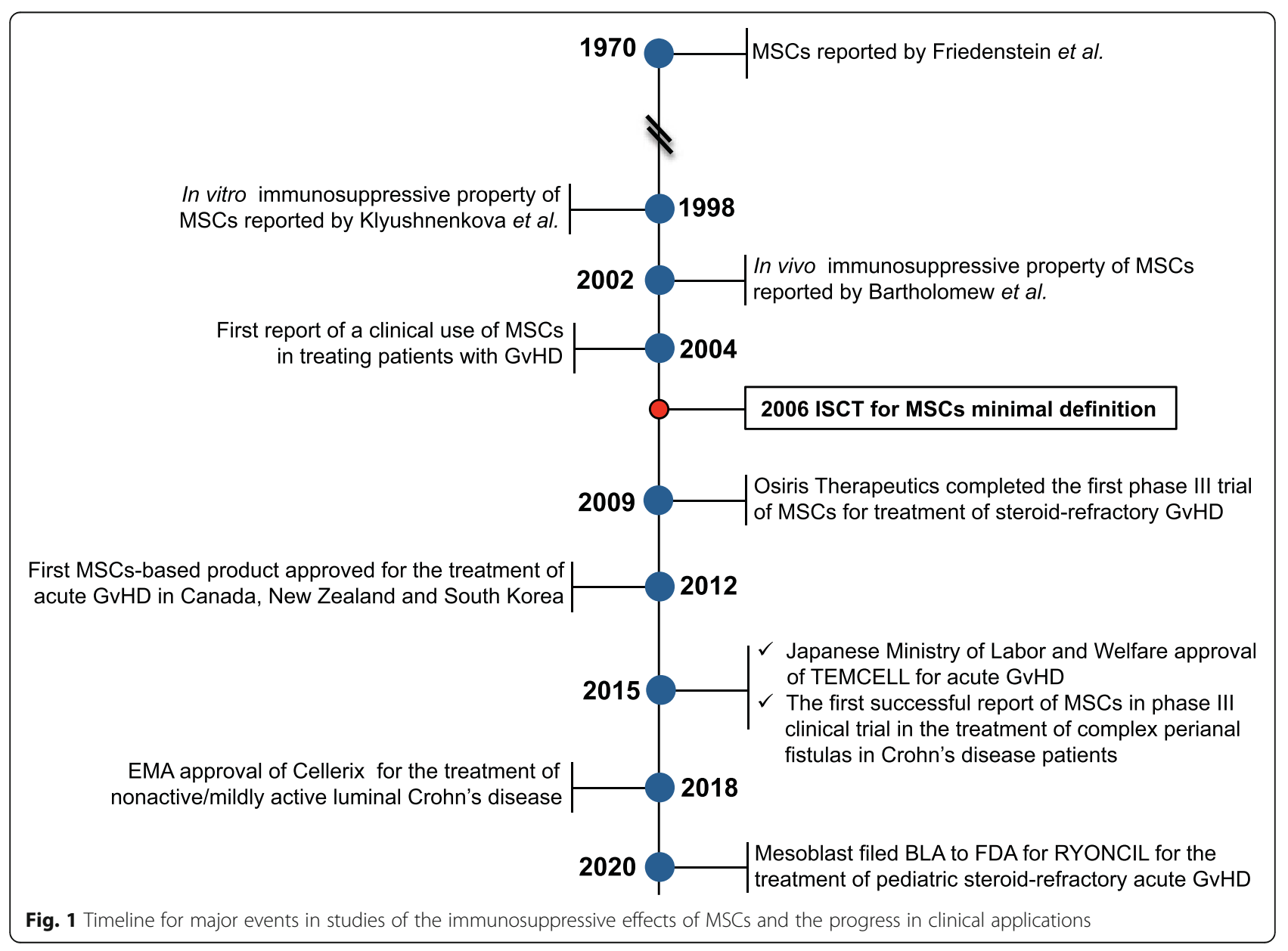


diabetes, lupus, arthritis, acute lung injury, Covid-19 [30], cirrhosis, and so on. Due to the accessibility, ease of isolation, and therapeutic efficacy, by far, the most prevalent source of human MSCs in clinical trials remains adult BM, followed by AT with an emergence of postpartum discarded tissues, such as umbilical cord, placenta, amniotic membranes, and cord blood [13]. Here we present an overview of the latest findings and medical translation of MSCs in preclinical studies and clinical applications.

\section{MSC therapy: biological properties supporting clinical use}

Clinical trials exploring MSC therapy have been driven predominately by companies pursuing the development and commercialization of proprietary allogeneic MSC products, such as Mesoblast's Remestemcel-L, Mesoblast's Revascor, Athersys' MultiStem, Stempeutic's Stempeucel, Stemedica's Stemdyne-MSC, Allocure's AC607, Pluristem's PLX-PAD and PLX-R18, TiGenix's Darvadstrocel, and Orthofix's Trinity Evolution. Briefly, pre-banked allogeneic MSCs derived from small groups of donors are subjected to culture expansion to generate therapeutic agents for treating allogeneic unrelated recipients [27, 31-34]. Though a uniform mechanism governing MSC-based therapy has not yet been demonstrated, the therapeutic potential of MSC deployment should be considered from bellow aspects: (i) paracrine effect by secreting soluble factors crucial for cell survival and proliferation, (ii) modulating immune responses, and (iii) migrating to the site of injury.

\section{Paracrine effects}

MSCs do not persist following infusion [35-38]. The therapeutic benefits of MSC transplants are mostly attributable to the so-called hit-and-run mechanism mediated by the production of EVs and the secretion of cytokines, chemokines, and growth factors, to exert effects during the initial days following MSC injection. With the majority of cells dying within $48 \mathrm{~h}$ [39-42], long-term engraftment has been found very limited and ectopic tissue formation rarely reported. Using donor DNA/RNA analysis, bioluminescence tracking, and intravital imaging, engrafted MSCs were shown to be short-lived [38]. Recently, tissues from 18 patients who received MHC-mismatched or haplo-identical MSCs were systemically analyzed, and basically, no ectopic tissue was observed [36], although high levels of donor DNA ( $>1 / 1000$ cells) were found in one patient at multiple sites; however, this patient was unrepresentative given he was severely immunocompromised and septic and received MSC infusion 7 days before his death [36]. Since intravascular infusion is the most popular route for clinical MSC delivery, the mechanisms mediating the persistence of systemically infused MSCs has mostly been studied, revealing a large fraction of infused therapeutic cells being lost due to their triggering of instant blood-mediated inflammatory reaction (IBMIR) [43, 44], resulting in MSCs rapidly embolized and destroyed in the microvasculature [13, 44].

On the other hand, over the years, our understanding of MSC functionality has undergone another paradigm shift that MSCs yield therapeutic benefits largely via paracrine effects and stimulation of host cells rather than cell replacement [22]. It has becoming increasingly evident that the therapeutic actions of MSCs are broadly attributed to numerous biologically active soluble substances secreted by MSCs to deliver immunomodulatory, angiogenic, antiapoptotic, and antioxidative effects. For instance, MSCs secrete vascular endothelial growth factor (VEGF), fibroblast growth factor (FGF), hepatocyte growth factor (HGF), placental growth factor (PGF), monocyte chemotactic protein 1 (MCP-1), stromal cellderived factor 1 (SDF-1), and angiopoietin-1 (Ang-1) that are critical for vascularization [45-52], enabling MSCs to ameliorate ischemia and chronic inflammation and facilitate wound repair [53-62]; MSCs synthesize and secrete B cell lymphoma 2 (BCL-2), survivin, VEGF, HGF, insulin-like growth factor-I (IGF-I), stanniocalcin1 (STC-1), transforming growth factor $\beta$ (TGF- $\beta$ ), FGF, and granulocyte-macrophage colony-stimulating factor (GM-CSF), inhibiting cellular apoptosis and restoring tissue homeostasis [63-66]; or MSCs modulate immune response principally via suppressive mediators, such as prostaglandin E-2 (PGE-2), soluble human leukocyte antigen G5 (sHLA-G5), TGF- $\beta$, HGF, IL-10, IL-6, indoleamine 2,3-dioxygenase (IDO), nitric oxide (NO), inducible nitric-oxide synthase (iNOS), hemeoxygenase-1 (HO-1), galectin-1 (Gal-1), Gal-9, and TNF $\alpha$ stimulated gene 6 (TSG-6), [25, 29, 41, 67-73]; moreover, MSCs regulate migration via a variety of chemokines such as CCR1, CCR2, CCR4, CCR7, CXCR5, and CCR10 [7477]. In all, MSCs mediated immunomodulation and regenerative activity is a redundant system and none of these molecules has an exclusive role. Depleting any one of these molecules would not result in a complete loss of the regulatory action it involved, and their relative contribution to the therapeutic effects of MSCs varies between different studies.

\section{Immunomodulation}

The discovery that bone marrow-derived MSCs might suppress co-cultured immune cells led to the intensive investigations of the immunomodulatory properties of MSCs [20]. In 2002, Bartholomew et al. found MSCs capable of suppressing the proliferation of co-cultured leukocytes in a dose-dependent manner, and regardless of MSC-donor origin, such suppression could be induced and observed [78]. Moreover, the addition of IL-2 
impaired MSC-mediated suppression, suggesting the process was partially reversible and MSCs did not induce $\mathrm{T}$ cell anergy $[78,79]$. The immunosuppressive potential of MSCs was thereby tested in baboon skin allograft model in vivo, with MSCs intravenous injection immediately conducted after transplanting MHC-mismatched skin graft. The administration of donor-matched or third-party MSCs was shown able to extend the survival of the skin graft from 7 days (control without MSCs) to 11.3 and 11.8 days, respectively, indicating MSCs promote tolerance to transplanted tissues and the inhibition is not MHC restricted [80]. This new insight that MSCs have unique immunologic characteristics underlying their survival and growth in allogeneic or xenogeneic environments potentially opened the avenue for MSCs in the applications of treating various immunology related disorders [81].

MSCs exert immune tolerant phenotype by expressing very low levels of major histocompatibility complex (MHC) Class I surface antigens, accompanied by reduced expression levels of the major components of the antigen processing machinery (APM), and do not express MHC Class II antigens unless inflammatory signaling stimulated [27, 29], FasL or co-stimulatory molecules such as CD80 (B7-1), CD86 (B7-2), CD40, or CD40L [11, 80-83]. In addition, MSCs release sHLA-G, a non-classical MHC Class Ib antigen that is typically involved in the establishment of immune tolerance at the maternal-fetal interface, as well as express the coinhibitory molecules B7-H1 (PD-L1) and B7-H4, to further prevent the immune attacking [84]. MSCs also dynamically express the Toll-like receptors (TLRs) 2, 3, 4, 7, and 9, affecting the pro- or anti-inflammatory properties of MSCs according to microenvironmental context. To fully explore MSC-mediated beneficial immunomodulation, particularly immunosuppression, in clinical application and implementation, the underlying mechanisms by which MSCs interact with the innate and adaptive immune cells shall be determined and are currently under in-depth investigation (summarized in Fig. 2).

\section{Effect of MSCs on dendritic cells (DCs)}

Dendritic cells maintain and modulate immune responses through dual effects. DCs can prime naïve CD4 ${ }^{+}$ $\mathrm{T}$ cells polarizing towards Th1, Th2, or Th17 effector T cells and stimulate $\mathrm{CD}^{+} \mathrm{T}$ cytotoxic activities; meanwhile, DCs can induce the expansion of immunosuppressive $\mathrm{CD}^{+}{ }^{+}$Treg cells and promote effector $\mathrm{T}$ cell apoptosis, enforcing immune tolerance [85-87]. Recent studies demonstrated that MSCs could block the differentiation and maturation of monocytes towards DCs

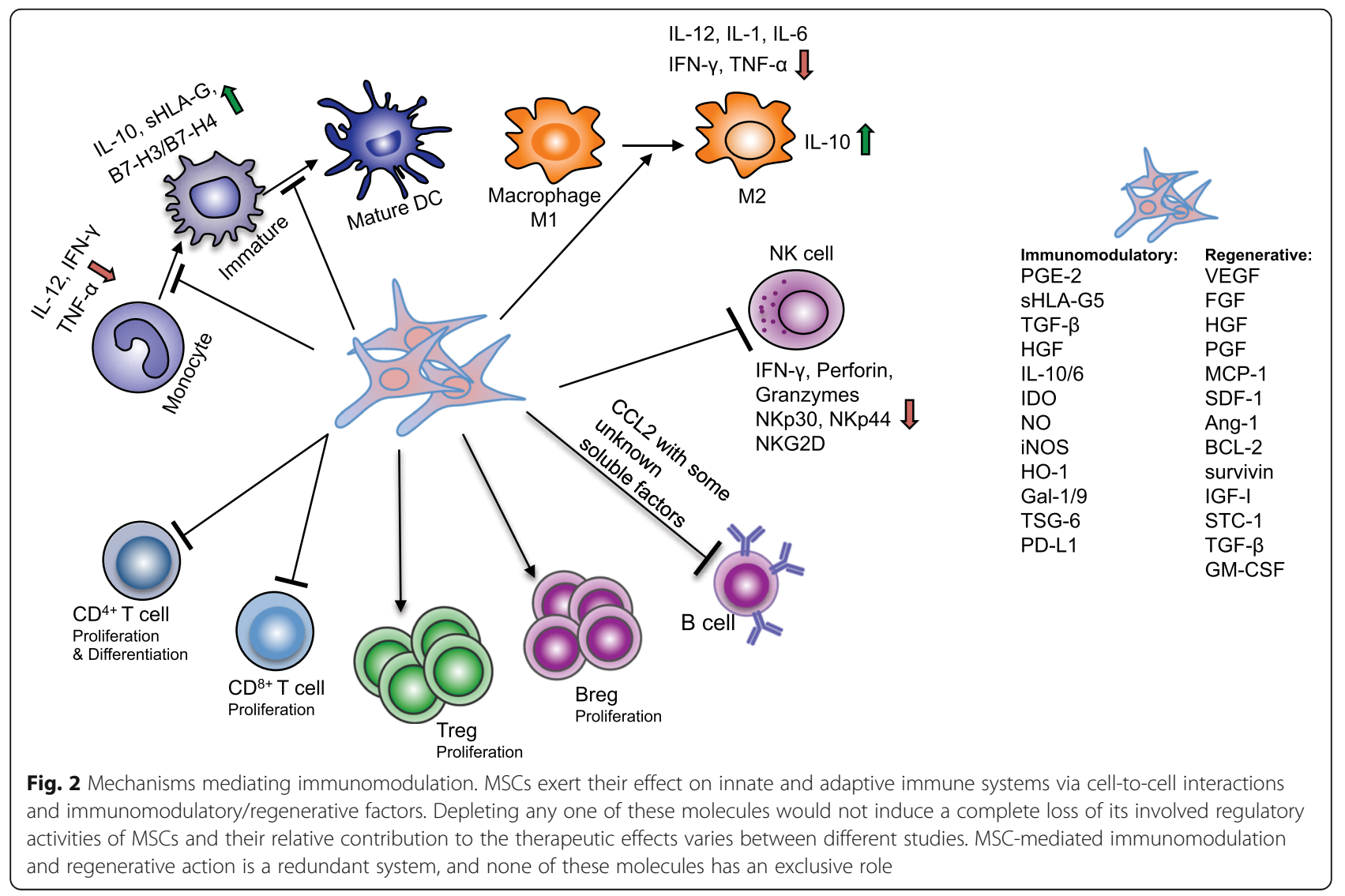


and decrease the cell-surface expression of CD1- $\alpha$, CD40, CD80, CD83, CD86, and MHC-II [70, 88, 89]. In the presence of MSCs, DCs also decrease the production and secretion of IL-12, interferon- $\gamma$ (IFN- $\gamma$ ), and TNF while accelerating IL-10 release [88], resulting in impaired ability of antigen presentation. In addition, the immunosuppressive traits of DC, such as sHLA-G or $\mathrm{B} 7-\mathrm{H} 3$ and $\mathrm{B} 7-\mathrm{H} 4$, typically involved in the protection of allogeneic transplants, were also increased in the presence of MSCs [90]. Lately, Reis et al. report the exosomes/microvesicles of MSCs significantly enriched with immunomodulatory microRNAs, such as miR-21-5p, miR-142-3p, miR-223-3p, and miR-126-3p, were capable of distinctively undermining immature DCs antigen uptaking as well as halting DC maturation [91].

\section{Effect of MSCs on natural killer (NK) cells}

As sensors for microbial products and sentinels of virus infected cells, NK cells can kill non-self and transformed cells lacking MHC class I molecules, together with targeting cells expressing the ligands capable of activating NK cell surface receptors [92]. In contrast to cytotoxic T cells, NK cells do not require prior antigen exposure to mediate their cytolytic activity [92]. MSCs can be strong inhibitors of NK cells in terms of proliferation and cytotoxicity. It has been shown the presence of MSCs substantially reduced IL-2/15-induced NK cell proliferation, cytotoxicity, the production of IFN- $\gamma$, and the level of perforin and granzymes [93-95]. Furthermore, the expression of surface receptors, such as NKp30, NKp44, and natural-killer group 2 member D (NKG2D) typically involved in NK cell activation and target cell killing, were also downregulated. In addition, immunosuppressive secretors PGE-2, TGF- $\beta$, IDO, and sHLA-G constitutively produced by MSCs also contribute to MSC-mediated NK cell inhibition. However, the potent suppressive effects of MSCs were only apparent at high MSC-to-NK ratios [96, 97]. Both autologous and allogeneic MSCs have been found dissolved by cytokineactivated NK cells when sufficient activating receptors expressing on NK cells [98]. Incubation of MSCs with IFN- $\gamma$ partially protected them from NK-cell-mediated cytotoxicity, suggesting a microenvironment rich in IFN- $\gamma$ might favor MSCs inhibiting NK cells, whereas in the absence of IFN- $\gamma$, the balance would be tilted towards NK cells eliminating MSCs [92-96, 98-100]. Similarly, it has been shown that TLR4-primed MSCs were more resistant than unprimed MSCs to activated NK cell killing, and in contrast, no comparable protection was observed after TLR7/ 8-priming of MSCs [97, 101-103]. Taken together, the capability of MSCs exerting suppressive effects on NK cells or the susceptibility of MSCs to NK-cell-mediated cytotoxicity depends on the complex interaction between two types of cells and the ratios between them, as well as the microenvironmental context.

\section{Effect of MSCs on macrophages}

Macrophages are key players in initiating and controlling immune response with significant plasticity [104]. In the context of inflammatory environment, typically with high levels of TNF- $\alpha$ and IFN- $\gamma$, MSCs have been widely reported to promote macrophage polarization towards anti-inflammatory M2 phenotype, downregulating the secretion of pro-inflammatory cytokines while upregulating phagocytic activities and the release of tropic factors and IL-10; whereas in the absence of local inflammatory cues, MSCs induce the differentiation of macrophages towards pro-inflammatory M1 phenotype through secretion of IFN- $\gamma$ and IL-1 as well as elevating the expression of CD40L on cell surface [105-107]. Some in vitro observations have been confirmed in in vivo studies, showing MSCs play an important role of educating macrophages to promote tissue repair during injury resolution. For instance, applying MSCs to treat renal damage after ischemia lessened the infiltration of macrophages and increased the proportion of M2 macrophages, combined with increased IL-1/6 production and secretion of IL-10 at ischemic sites [108]. In an animal model of skin wound healing, it has also been shown MSCs were capable of improving wound closure, dampening the M1 inflammatory response and promoting the induction of M2 macrophages [109].

\section{Effect of MSCs on T lymphocytes}

In adaptive system, MSCs can modulate the intensity of immune response by inhibiting antigen-specific $\mathrm{T}$ cell proliferation and cytotoxicity, as well as promoting the generation of regulatory $\mathrm{T}$ cell (Treg) [110]. It has been demonstrated that in vitro $\mathrm{T}$ lymphocyte proliferation induced by polyclonal mitogens, allogeneic cells, or specific antigen can be considerably inhibited by MSCs. MSCs are capable of promoting apoptosis of activated T cells via the Fas/Fas ligand pathway [111], as well as constitutively secreting inhibitory mediators such as B7-H4, HLA-G, PGE2, IDO, NO, and HO-1 [112, 113]. The release of these suppressive factors can be enhanced following stimulation of MSCs with TNF$\alpha$ and IFN- $\gamma$ [114-116]. Furthermore, several studies have reported the ability of MSCs to polarize T cells towards immunosuppressive regulatory phenotype, dampening inflammation [11, 35]. Particularly, soluble mediator IDO promotes the degradation of tryptophan to generate kynurenine and numerous other catabolites, which have been shown to contribute greatly to suppressing $\mathrm{T}$ cell proliferation and inducing Treg cells $[117,118]$. Very importantly, fail-safe mechanism exists in MSCs' actions, preventing excessive inhibition of $\mathrm{T}$ cell responses and host being vulnerable to infectious agents [11, 119]. MSCs can acquire distinct immunophenotypes through TLRs in accordance with microbe-associated molecular patterns in the microenvironment [11]. For instance, TLR4-primed MSC 
population exhibits a pro-inflammatory profile, and TLR3primed MSC population delivers anti-inflammatory immunomodulation [120], enabling MSCs to influence the functionality of $\mathrm{T}$ cells depending on the microenvironment. It has been found MSCs may lose the ability to inhibit T cell proliferation following the exposure to pathogen-associated ligands and triggering the expression of TLR4 due to impaired Notch signaling [119, 121-123]. In short, pathogenassociated molecules could reverse the suppressive effects of MSCs on T cells and restore efficient T cell responses to pathogens.

\section{Effect of MSCs on B lymphocytes}

$B$ cells are the second major cell population related to adaptive immune response, and it has been shown MSCs are capable of suppressing B cell proliferation, reducing plasmablast formation as well as promoting induction of regulatory B cells (Bregs) [124, 125]. Bregs have immunosuppressive properties usually mediated by IL-10 secretion, through which they provide immunological tolerance and convert effector $\mathrm{CD} 4^{+} \mathrm{T}$ cells into Foxp $3^{+}$ Tregs [126]. In addition, MSCs have been shown to affect the chemotactic properties of $\mathrm{B}$ cells, as the CXCR4, CXCR5, and CCR7 in B cell expression were significantly downregulated in the presence of MSCs, along with declined chemotaxis to CXCL12/13, the CXCR4/5 ligands $[125,126]$. Both cell-contact and secreted factors are needed for MSC modulation of B cells [127]. In particular, metalloproteinase processed CCchemokine ligand 2 (CCL2) released by MSCs was found to suppress the activity of signal transducer and activator of transcription 3 (STAT3) signaling pathway and thus inhibit immunoglobulin synthesis in B cells via compromising PAX5 function [128]. Several other signaling pathways, such as B lymphocyte-induced maturation protein 1 (Blimp1), p38, extracellular response kinase 1/ 2 (ERK1/2), and PI3K/AKT/mTOR signaling, also negatively modulate B cell activation [129]. However, similar to mediating $\mathrm{T}$ cell activity, inadequate inflammatory signal-activated MSCs may support proliferation and differentiation of antibody-releasing B cells [130, 131], meaning MSC suppressive effects relying on the strength of the inflammatory stimulation to yield the plasticity of MSC immunomodulation [10, 132, 133].

\section{Homing and hemocompatibility consideration}

One of the key benefits of MSC-based therapies is their ability to preferentially migrate to damaged tissues exhibiting inflammation [134]. Although in situ administration can directly achieve this goal, this possibility can be hampered by the anatomical location of the damaged tissue or by the systemic nature of the illness [11]. Basically, in non-systemic homing, MSCs are transplanted locally at the target tissue and then guided to the site of injury via a chemokine gradient, whereas in systemic homing, systemically administered MSCs must undergo a multistep process to exit circulation and migrate to the injury site, supporting functional recovery [74].

The initial tethering step (illustrated in Fig. 3) is mediated by selectins expressed by endothelial cells and CD44 expressed by MSCs [135-137]. The interaction between these two factors facilitates MSCs to begin rolling along the vasculature wall. However, as most understanding of migration and homing mechanisms derived from studies evaluating leucocytes migrating into inflamed tissues, the fact that MSCs do not express the hematopoietic cell E-/L-selectin ligand (HCELL) [135], a specialized glycoform of CD44 on the migrating cell, as well as the P-selectin glycoprotein ligand-1 (PSGL-1) [135], raises the question of which selectin exactly employed by MSCs. One study has identified galectin-1 [138] as one such candidate, and another study has identified CD24 as a potential P-selectin ligand [139]. Following the initiation of tethering step, activation step is facilitated typically by $\mathrm{G}$ protein-coupled chemokine receptors in response to inflammatory signals. It has been extensively demonstrated that the CXCR4-SDF-1 axis is critical for this step [140, 141]. However, the expression of the chemokine receptor CXCR4 on MSCs is inconsistently observed, suggesting that other receptors are also involved, for some groups did not observe expression of the receptor while other studies demonstrated overexpression of CXCR4 on MSCs affected migration in response to SDF-1 [142-144]. Indeed, aside from CXCR4, MSCs express CCR1, CCR4, CCR7, CCR10, CCR9, CXCR5, and CXCR6 $[75,76]$, of which their roles remain to be elucidated in detail. Integrins play a critical role in the activation-dependent arrest in the third step of homing, with integrin $\alpha 4$ and $\beta 1$ subunit combined to form very late antigen 4 (VLA-4) that capable of interacting with vascular cell adhesion molecule 1 (VCAM-1) to enable arrest [145]. Inhibiting integrin $\beta 1$ subunit has been shown to abolish MSC homing [141, 145, 146]. In the final step, MSCs must travel through the basement membrane underlying endothelial cells, which requiring various matrix metalloproteinases (MMPs) to cleave the components of the connective tissue [145]. As the gelatinases MMP-2 and MMP-9 preferentially degrade collagen and gelatin, they play significant roles in this step [147-149]. It has also been shown this step is regulated by tissue inhibitor metalloproteinase 3 (TIMP-3), TIMP-2, and membrane type 1 MMP (MT1-MMP), and very likely, there are more molecular interactions involved in MSC extravasation [150, 151]. Finally, guided by chemotactic signals, MSCs must migrate to the site of injury. MSCs migrate towards various signals, including the growth factors platelet-derived growth factor- $\mathrm{AB}$ (PDGF-AB) and insulin-like growth 


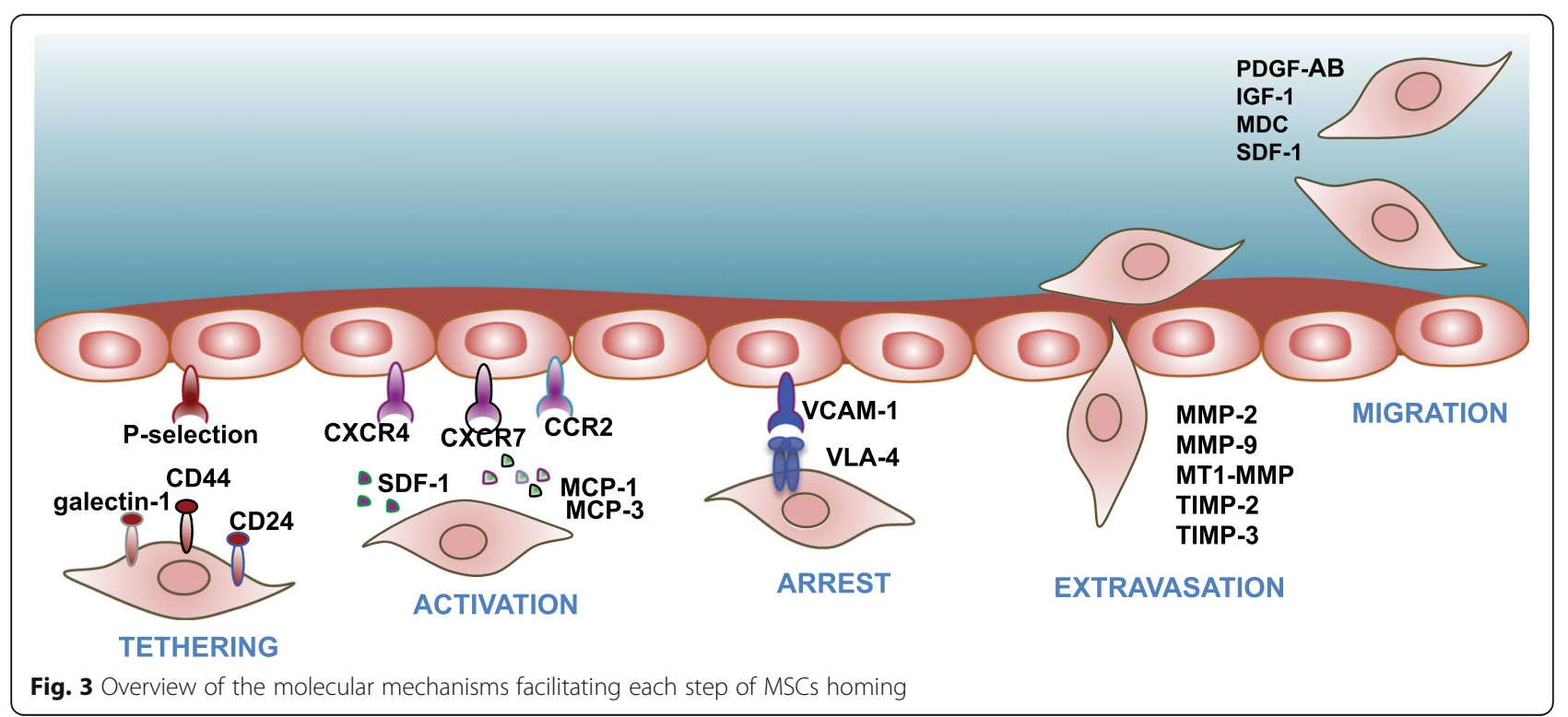

factor 1 (IGF-1), and to a lesser extent, the chemokines MDC and SDF-1 [74].

As mentioned above, the majority of infused therapeutic MSCs are lost due to their triggering of IBMIR, mediated primarily by the innate coagulation and complement cascade system, thus assessing and controlling hemocompatibility should be considered and implemented for safer and more effective MSC therapies. Firstly, eliciting IBMIR by MSC products is correlated with their expression of tissue factor (TF/CD142) [43, $152,153]$, which has been found to be a potent trigger of coagulation. The pro-coagulant effect of MSCs increases as TF expression elevated, and MSC's TF expression has been found upregulated as cell passage increases [44]. Secondly, the complement cascade capable of initiating innate immune attack and MSC embolization is another major leading cause of IBMIR $[43,153,154]$. Therefore, Moll et al. suggested hemocompatibility profiling and testing of complement compatibility should be conducted in vitro as well as in vivo, in addition to standardization of cell reconstitution, supplementing the formulation with additives such as anticoagulants, to optimize the stability, tolerability, and performance of MSC products [13].

\section{MSC-based cell therapy}

MSCs represent a significant fraction of the current efforts to develop cell-based treatments for a range of diseases, and the number of clinical trials has been substantially rising since the last decade. Querying the ClincalTrials.gov international database provides important insight into the development of MSC applications in clinical trials. Currently, there are 1094 registered clinical trials in different clinical phases throughout the world (Accessed 24 April
2020). Among 1094 registered trials, 320 trials are completed and 77 studies are in the status of being withdrawn/terminated/suspended, whereas the rest are in the active status; 208 studies are recruiting and 104 studies not yet starting to recruit; most of these trials are phase III studies (847 studies), and less than 6\% studies in the phase III or the combination of phase II/III (64 studies), whereas very small numbers of these trials are in phase III or phase III/IV (6 studies). To date, 149 trials are registered for immune-related disease, including 47 for GvHD, 25 for Crohn's disease, 26 for type 1 diabetes, 29 for MS, and 14 for lupus, as well as 146 trials for cardiovascular diseases, 54 for liver disorders, 82 for respiratory disorders, 22 for Covid-19, 33 for spinal cord injury, 18 for kidney failure, 62 for skin diseases, 13 for Alzheimer disease (AD), 7 for Parkinson disease (PD), and rest are for other conditions. Here, we discuss some of the recent clinical developments, focusing on the registration trials paving the path for the commercialization of MSCs for GvHD and Crohn's disease.

\section{MSCs in GvHD}

Graft-versus-host disease (GvHD) accompanies allogeneic hematopoietic stem cell transplantation (HSCT) in many patients and is associated with high morbidity and mortality [155]. GvHD is a form of rejection characterized by the attack of transplanted cells to host tissues and organs. It has been estimated that nearly $50 \%$ of all allogeneic blood and marrow transplant patients develop acute GvHD [156]. Liver or gastrointestinal involvements occur in up to $40 \%$ of all patients with acute GvHD and are associated with the greatest risk of death, with mortality rates of up to $85 \%$. Currently, corticosteroids remain to be the gold standard for the initial 
treatment of acute GvHD with the response rate of 50 $80 \%[155,157,158]$. However, it has been only $10-30 \%$ chance of long-term survival for the patients whose initial therapy failed. Immunoregulation capability of MSCs suggests their potential application in lessening GvHD severity and facilitating the engraftment of HSCs [26]. In 2004, Le Blanc et al. first transplanted haploidentical MSCs in a 9-year-old boy with severe treatmentresistant grade IV acute GvHD of the gut and liver [26]. One-year follow-up observations reported a remarkable clinical response and improvement.

Subsequently, the first major industry-sponsored phase III trial of allogeneic, BM MSCs for the treatment of steroid-refractory GvHD (NCT00366145) was conducted and completed by Osiris Therapeutics. The MSCs were sourced from healthy volunteers and then manufactured and cryobanked as allogeneic MSC product of Prochy$\mathrm{mal}^{\mathrm{TN}}$. For the primary endpoint, the overall response rate was $82 \%$ with Prochymal versus $73 \%$ for placebo, failing to demonstrate a significant advantage of Prochymal over placebo. In retrospective, subset analysis revealed the improvement in children, which ultimately led to its approval in Canada via a Notice of Compliance with Conditions (NOC/c). In 2013, the Prochymal assets were acquired by Mesoblast that sponsored adaptive clinical trial of MSCs in pediatric GvHD (NCT02336230), and the cellular product was renamed as Remestemcel-L. Based on various observations obtained on previous clinical trial NCT00366145, children responded better than adults to allogeneic MSCs overall, after onset treating patients early on was better than delayed intervention, gut and liver GvHD were more responsive than skin type, multiple modifications were implemented in NCT02336230, including age of inclusion, severity of disease, starting time for MSC transfusion, the definition of response, and as exclusion of skin-only GvHD, while maintaining applying identical MSC products and dosing schemes in both clinical trials. The recruitment was completed in December 2017, and in February 2018, it was announced treatment with Remestemcel-L significantly improved the overall response rate at day $28(69 \%)$ compared with the protocoldefined historical control rate of $45 \%(p=.0003)$. In addition, an overall survival rate at 6 months for the MSCtreated group was shown to be $69 \%$, a considerable improvement compared with the historical survival rates of $10-30 \%$ in patients with steroid refractory grade III and IV GvHD. With these results [159-163], Biologics License Application (BLA) for Remestemcel-L (Ryoncil ${ }^{\mathrm{T}}$ ) for the treatment of children with steroid-refractory acute GvHD has been lately accepted for the priority review by the US FDA, which has set a Prescription Drug User Fee Act (PDUFA) action date of September 30, 2020, and if approved, Remestemcel-L will be commercially available in the USA.

\section{MSCs in Crohn's disease}

Crohn's disease is a chronic inflammatory disorder of gastrointestinal tract [164, 165]. In the early 1990s, Crohn's disease patients were reported to experience relief from their inflammatory bowel disease following infusion of HSCs, and subsequently, HSC transplantation has been developed for refractory patients that do not respond to conventional treatments involving steroids or immunosuppressive agents or anti-TNF therapy [166168]. However, serious adverse effects accompanied HSC transplantation treatment [169-172], which triggered the attempts to employ allogeneic or autologous MSCs for Crohn's disease therapy. Early phase studies reported encouraging observations and autologous BMMSC exhibited efficacy with improved Crohn's disease activity index scores [173-176]. More recently, Cellerix sponsored the clinical trial NCT00475410 of adiposederived autologous MSCs for the treatment of complex perianal fistulas in patients without inflammatory bowel disease. The study completed enrollment of 214 subjects in 2009; however, examining the primary endpoint of sustained closure and healing of fistulas 6 months after treatment failed to demonstrate that the adipose MSC application was superior to applying fibrin glue alone. In 2011, Cellerix was acquired by TiGenix which next sponsored an adaptive phase III trial with various changes: replacing autologous with allogeneic adipose MSCs, increasing the cell dose considerably, no fibrin glue matrix was applied, and only enrolling the patients with Crohn's disease.

In 2015, this TiGenix-sponsored randomized, doubleblind, placebo-controlled phase III clinical trial (NCT01541579) [177, 178] was completed, reporting statistically significant improvement over control in the treatment of complex perianal fistulas in Crohn's disease patients, which represents the first unambiguously successful use of MSCs in an advanced clinical trial [27]. Significant difference was observed in patients treated with allogeneic adipose MSCs (50\%) versus control (34\%) after 24 weeks. Moreover, less treatment-related adverse events were observed in the allogeneic adipose MSCs group, with the therapeutic benefit and the good safety profile maintained after 1 year of treatment. In March 2018, TiGenix received the approval of its first allogeneic adipose MSC

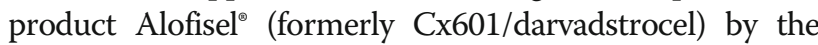
European Medicines Agency (EMA) to treat complex perianal fistulas in adult patients with nonactive/mildly active luminal Crohn's disease.

\section{MSCs in cardiovascular diseases}

Cardiovascular diseases (CVDs) affecting both heart tissue and circulatory system, especially blood vessels, are today leading cause of mortality worldwide [179-182]. As the least regenerative organ in the human body, scar 
forms following myocardial infarction (MI) due to the loss of cardiomyocytes and being replaced with fibroblasts, leading to contractile dysfunction of the heart $[183,184]$. The potential capability of MSCs differentiating into mesoderm- and non-mesoderm-derived tissues, their immunomodulatory and regenerative effects, and overall availability have rendered MSCs one of the most intensively investigated and clinically tested cell type for CVDs. Autologous and allogeneic MSCs were employed to treat numerous acute as well as chronic cardiomyopathies in preclinical trials [185-189], suggesting safety, effectiveness of reduction in arrhythmias, improvement in functional status and increased ejection fraction. For clinical trials, MSCs have been used to treat pediatric cardiomyopathy, congenital heart diseases (hypoplastic left heart syndrome), refractory angina, myocardial infarction, and chronic ischemic cardiomyopathy [190194]. Comparing the results of preclinical studies to those of clinical trials, only marginally beneficial effects could be observed in the latter [183, 184, 195-197]. In comparison, chronic ischemic cardiomyopathy could be more easily yielding consensus with preclinical observations thanks to various perceptible beneficial effects, including anti-fibrotic action, neo-angiogenesis, and contractility enhancement [198-204].

Autologous MSC-based therapy has emerged as a fast developing treatment modality for CVDs. In attempt to evaluate the safety and effectiveness of autologous MSCs, a total of 31 patients suffering from stable coronary artery disease and refractory angina received the intramyocardial injection of autologous marrow-derived MSCs. Significant improvement in left ventricular function and exercise capacity was reported in this study, in addition to various improvements in clinical symptoms [205]. Subsequently, these positive results were confirmed by a placebo controlled phase II trial evaluating the treatment of patients with chronic ischemic heart failure via the intramyocardial delivery of autologous MSCs. A total of 60 patients were randomized to receive the injection of either MSCs or placebo, and after 12 months, MSC infusion appeared to have induced the regeneration of damaged myocardial tissue along with the improved functional capacity of heart [204]. In a recently completed sham-controlled phase III trial for the treatment of chronic advanced ischemic heart failure (NCT01768702) [206], autologous marrow-derived MSCs were polarized to undergo lineage specification to acquire cardiopoietic phenotype and then administrated via endomyocardial injections. The primary endpoint results were unable to demonstrate significant difference between MSC intervention group and placebo after 39 weeks. However, the analysis of ventricular remodeling 52 weeks after treatment revealed that reverse remodeling was evident in patients receiving cardiopoietic MSCs, suggesting some beneficial effects [27, 204, 207].

\section{MSCs in autoimmune diseases}

MSCs are also employed to alleviate various debilitating autoimmune disorders, such as systemic lupus erythematosus (SLE), type 1 diabetes, and MS, among others $[29,32,129,208]$. SLE is a chronic autoimmune multiorgan-involved inflammatory disorder, characterized by aberrant activation of effector $\mathrm{T}$ lymphocytes and development of autoantibodies to nuclear antigens [209-213]. Lupus nephritis being the most prevailing organ manifestation is the major cause of mortality and morbidity in SLE patients [211, 214, 215]. For the past 20 years, no novel prospective clinical trial has demonstrated its effectiveness for SLE and there is an urgent unmet need to develop more effective therapies based on immunomodulatory and immunosuppressive strategies with fewer side effects, for which MSC application in the treatment of SLE has been explored. Recently allogeneic bone marrow or umbilical cord-derived MSCs were applied to the treatment of 87 refractory SLE patients [216] in open-label single armed phase I/II clinical trial (NCT01741857). Their results showed 32.5\% of patients reached a significant clinical efficacy with a welltolerated safety and a dramatic decline in disease activity scores review [129]. Of note, the promising report derived from NCT01741857 has not yet led to any advanced phase of clinical trial. Currently, there are four active clinical trials with a targeted enrollment of 137 patients listed in the ClinicalTrial Database.

Type 1 diabetes is a form of diabetes mellitus that results from $\mathrm{T}$ cell-mediated autoimmune destruction of insulin-producing pancreatic $\beta$ cells as well as decreasing insulin secretion owing to anti-islet autoantibodies [217, 218]. Insulin application and blood glucose control is the standard therapeutic methods for type 1 diabetes. However, adverse effects are accompanied by intense insulin injection, and maintaining normal glycemic levels is often difficult and associated with increased frequency of hypoglycemic episodes, prompting new strategies to tackle this emerging global epidemic [219, 220]. It has been demonstrated that MSCs could differentiate into glucose competent pancreatic insulin-producing cells (IPCs) in vitro as well as in vivo [221-223], in addition to the capacity to regulate the immunomodulatory effects. It has been showed that transplantation of BM cells and MSCs in sublethally irradiated diabetic mice could regenerate islet $\beta$ cells and reinforce glycemic control of type 1 diabetes; in their study, combined BMCs and MSCs infusion appeared to be synergistic [224, 225]. Recently, in a randomized controlled open-label phase I/ II clinical trial (NCT01374854), cotransplantation of 
allogeneic Wharton's jelly UC-MSC combined with autologous bone marrow mononuclear cell was shown to improve insulin secretion and reduce insulin requirement compared with baseline and the standard treatment controlled group [224]. Currently, there are six active clinical trials with a targeted enrollment of 172 patients listed in the ClinicalTrial Database.

MS is a chronic autoimmune condition due to the demyelination of the central nervous system (CNS). MS is one of the most prevalent autoimmune diseases mediated by pathogenic $\mathrm{CD} 4^{+} \mathrm{T}$ cells in the CNS. Although there are 2.3 million people influenced by this disease $[226,227]$, there is no effective means to stop the progression of disease and induce remyelination. Immunomodulation featured treatments have been exploited to ameliorate inflammation and neurodegeneration, with some MSC transplantation studies showing improved outcome in the MS animal model of experimental allergic encephalitis (EAE) [228, 229]. In addition, several disease models demonstrate axonal neuroprotection following MSC application, presumably achieved by MSCmediated immunosuppression and the production of regenerative neurotrophic/growth factors [230-234]. Currently, there have been 29 clinical trials of MS registered on the ClinicalTrial Database utilizing MSC therapy as medical interventions, and based on completed phase I/ II trials, autologous BM MSCs are suggested to be neuroprotective and safe in treating MS patients [235].

\section{Future perspective}

As Pittenger et al. lately described that MSCs were initially started as "a riddle wrapped in a mystery, inside an enigma" [29], years of research have shown MSCs are capable of exerting profound immunomodulatory and regenerative action, making MSC-based treatment one of the most promising and intensely pursued cellular therapies. At present, more than 1000 MSC clinical trials have been registered globally, enabling meta-analysis to demonstrate MSC application safety [22]. However, the clinical efficacy and our understanding of the underlying molecular mechanism for a variety of pathological conditions remain to be improved. The combination of rational selection of subjects according to clinical and biological parameters and better understanding of cell manufacturing, banking, and point of care deployment is key to yield an optimal short- and long-term therapeutic benefit [27]. Furthermore, preclinical data support the notion that the use of priming MSCs either by use of pharmaceutical agents or cytokines, genetic engineering, or reprogramming MSCs prior to infusion enhances their pharmaceutical potency and hemocompatibility, encouraging novel translational strategies. Moreover, there are currently more than 200 preclinical investigations and a few clinic studies being carried out to exploit the immunosuppressive and immunomodulatory properties of EVs derived from the MSCs [236]. In comparison to whole cell-based therapies, MSC-EV-related therapeutics promotes concept of cell-free "cell therapy 2.0" [237], given EV exhibiting specific advantages for patient safety such as lower propensity to trigger innate and adaptive immune responses and inability to directly form tumors. Nonetheless, various important questions regarding EV standardization, MoA underlining EV transmitted biological information in the form of proteins, glycoproteins, lipids and ribonucleic acids, and costeffective production must be methodically addressed [236-240].

In conclusion, the pace of the clinical trials based on MSC-mediated therapies is outstripping the progress in its basic research, presenting a great challenge of establishing guidance but also creating an opportunity to deepen our understanding of therapeutic MSCs. To achieve optimal stability, tolerability, and performance of next-generation MSCs therapies, efforts are underway to improve product design and delivery, safety and potency assessment pre- and post-treatment, and the understanding of the exact MoA with the advancement of transcriptomic, proteomic-profiling technology.

\section{Abbreviations}

MSCs: Mesenchymal stem cells; BM: Bone marrow; ISCT: International Society for Cellular Therapy; HLA-DR: Human leukocyte antigen-DR isotype; EV: Extracellular vesicle; DCs: Dendritic cells; GvHD: Graft versus host disease; MI: Myocardial infarction; MS: Multiple sclerosis; ALS: Amyotrophic lateral sclerosis; hMSCs: Human mesenchymal stem cells; AT: Adipose tissue; PT: Perinatal tissue; IBMIR: Instant blood-mediated inflammatory reaction; VEGF: Vascular endothelial growth factor; FGF: Fibroblast growth factor; HGF: Hepatocyte growth factor; PGF: Placental growth factor; MCP-

1: Monocyte chemotactic protein 1; SDF-1: Stromal cell-derived factor 1; Ang-1: Angiopoietin-1; BCL-2: B cell lymphoma 2; IGF-I: Insulin-like growth factor-1; STC-1: Stanniocalcin-1; TGF- $\beta$ : Transforming growth factor $\beta$; GMCSF: Granulocyte-macrophage colony-stimulating factor; PGE-

2: Prostaglandin E-2; sHLA-G5: Soluble human leukocyte antigen G5; IL: Interleukin; IDO: Indoleamine 2,3-dioxygenase; NO: Nitric oxide;

iNOS: Inducible nitric-oxide synthase; HO-1: Hemeoxygenase-1; Gal-

1: Galectin-1; TNF: Tumor necrosis factor; TSG-6: TNFa stimulated gene 6; CCR: C-C motif chemokine receptor; CXCR5: C-X-C motif chemokine receptor type 5; MHC: Major histocompatibility complex; APM: Antigen processing machinery; TLRs: Toll-like receptors; IFN-y: Interferon-y; NK: Natural killer; NKG2D: Natural-killer group 2 member D; Treg: Regulatory T cell; Breg: Regulatory B cells; CCL2: CC-chemokine ligand 2; STAT3: Signal transducer and activator of transcription 3; PAX5: Paired box 5; Blimp1: B lymphocyte-induced maturation protein 1; ERK1/2: Extracellular response kinase 1/2; HCELL: Hematopoietic cell E-/L-selectin ligand; PSGL-1: P-selectin glycoprotein ligand-1; VLA-4: Very late antigen 4; VCAM-1: Vascular cell adhesion molecule 1; MMP: Matrix metalloproteinase; TIMP-3: Tissue inhibitor metalloproteinase 3; MT1-MMP: Membrane type 1 MMP; PDGF-AB: Plateletderived growth factor-AB; IGF-1: Insulin-like growth factor 1;

MDC: Macrophage-derived chemokine; AD: Alzheimer disease; PD: Parkinson disease; HSCT: Hematopoietic stem cell transplantation; NOC/c: Notice of Compliance with Conditions; BLA: Biologics License Application; PDUFA: Prescription Drug User Fee Act; EMA: European Medicines Agency; CVDs: Cardiovascular diseases; SLE: Systemic lupus erythematosus; IPCs: Insulin-producing cells; CNS: Central nervous system; EAE: Experimental allergic encephalitis 


\section{Acknowledgements}

The authors wish to thank Dr. Rudolf Gehring and Dr. Lucy Spang for the useful discussions.

\section{Authors' contributions}

XW and XL contributed to the conceptualization of this review. XW contributed to writing the first draft of this review. YC, JJ, ZG, and JZ contributed to finalizing the review. All authors read and approved the final manuscript.

\section{Funding}

This work was supported by the Science Foundation of Fuzhou (Grant No. 2019-S-95); the Key Clinical Specialty Discipline Construction Program of Fuzhou, Fujian, China (Grant No. 201807111); and the Clinical Medicine Center Construction Program of Fuzhou, Fujian, China (Grant No. 2018080309).

\section{Availability of data and materials}

The data sets supporting the results of this article are included within the article.

\section{Ethics approval and consent to participate} Not applicable.

\section{Consent for publication}

Not applicable.

\section{Competing interests}

The authors declare that they have no competing interests.

\section{Author details}

'Dermatology Institute of Fuzhou, Dermatology Hospital of Fuzhou, Xihong Road 243, Fuzhou 350025, China. ${ }^{2}$ Department of Biomedicine, University of Basel, Klingelbergstr 70, CH-4056 Basel, Switzerland. ${ }^{3}$ The Institute of Biomedical Sciences, Fudan University, Mingdao Building, Dongan Road 131, Shanghai 200032, China. ${ }^{4}$ The United Innovation of Mengchao Hepatobiliary Technology Key Laboratory of Fujian Province, Mengchao Hepatobiliary Hospital of Fujian Medical University, Xihong Road 312, Fuzhou 350025, China.

Received: 8 May 2020 Revised: 9 July 2020

Accepted: 27 July 2020 Published online: 08 August 2020

\section{References}

1. Caplan Al. Mesenchymal stem cells. J Orthop Res. 1991;9:641-50.

2. Friedenstein AJ, Gorskaja JF, Kulagina NN. Fibroblast precursors in normal and irradiated mouse hematopoietic organs. Exp Hematol. 1976;4:267-74.

3. Friedenstein AJ, Piatetzky S II, Petrakova KV. Osteogenesis in transplants of bone marrow cells. J Embryol Exp Morphol. 1966;16:381-90.

4. Friedenstein AJ, Chailakhyan RK, Latsinik NV, Panasyuk AF, Keiliss-Borok IV. Stromal cells responsible for transferring the microenvironment of the hemopoietic tissues. Cloning in vitro and retransplantation in vivo. Transplantation. 1974;17:331-40.

5. Friedenstein AJ, Chailakhjan RK, Lalykina KS. The development of fibroblast colonies in monolayer cultures of guinea-pig bone marrow and spleen cells. Cell Tissue Kinet. 1970;3:393-403.

6. Friedenstein AJ, Chailakhyan RK, Gerasimov UV. Bone marrow osteogenic stem cells: in vitro cultivation and transplantation in diffusion chambers. Cell Tissue Kinet. 1987;20:263-72.

7. Pittenger MF, Mackay AM, Beck SC, Jaiswal RK, Douglas R, Mosca JD, et al. Multilineage potential of adult human mesenchymal stem cells. Science. 1999;284:143-7.

8. Nombela-Arrieta C, Ritz J, Silberstein LE. The elusive nature and function of mesenchymal stem cells. Nature reviews. Mol Cell Biol. 2011;12:126-31.

9. Wilson A, Webster A, Genever P. Nomenclature and heterogeneity: consequences for the use of mesenchymal stem cells in regenerative medicine. Regen Med. 2019;14:595-611.

10. Lukomska B, Stanaszek L, Zuba-Surma E, Legosz P, Sarzynska S, Drela K. Challenges and controversies in human mesenchymal stem cell therapy. Stem Cells Int. 2019;2019:9628536.

11. Uccelli A, Moretta L, Pistoia V. Mesenchymal stem cells in health and disease. Nat Rev Immunol. 2008;8:726-36.
12. Yin JQ, Zhu J, Ankrum JA. Manufacturing of primed mesenchymal stromal cells for therapy. Nat Biomed Eng. 2019;3:90-104.

13. Moll G, Ankrum JA, Kamhieh-Milz J, Bieback K, Ringden O, Volk HD, et al. Intravascular mesenchymal stromal/stem cell therapy product diversification: time for new clinical guidelines. Trends Mol Med. 2019;25:149-63.

14. Viswanathan S, Shi Y, Galipeau J, Krampera M, Leblanc K, Martin I, et al. Mesenchymal stem versus stromal cells: International Society for Cell \& Gene Therapy (ISCT(R)) Mesenchymal Stromal Cell committee position statement on nomenclature. Cytotherapy. 2019;21:1019-24.

15. Dominici M, Le Blanc K, Mueller I, Slaper-Cortenbach I, Marini F, Krause D, et al. Minimal criteria for defining multipotent mesenchymal stromal cells. The International Society for Cellular Therapy position statement. Cytotherapy. 2006;8:315-7.

16. Horwitz EM, Le Blanc K, Dominici M, Mueller I, Slaper-Cortenbach I, Marini FC, et al. Clarification of the nomenclature for MSC: the International Society for Cellular Therapy position statement. Cytotherapy. 2005;7:393-5.

17. Crisan M, Yap S, Casteilla L, Chen CW, Corselli M, Park TS, et al. A perivascular origin for mesenchymal stem cells in multiple human organs. Cell Stem Cell. 2008;3:301-13.

18. Bianco P, Robey PG, Simmons PJ. Mesenchymal stem cells: revisiting history, concepts, and assays. Cell Stem Cell. 2008:2:313-9.

19. Mendicino M, Bailey AM, Wonnacott K, Puri RK, Bauer SR. MSC-based product characterization for clinical trials: an FDA perspective. Cell Stem Cell. 2014;14:141-5.

20. Klyushnenkova E, Mosca JD, McIntosh KR, Thiede MA. Human mesenchymal stem cells suppress allogeneic T cell responses in vitro: implications for allogeneic transplantation [abstract]. Blood. 1998;92:642a.

21. Le Blanc K, Mougiakakos D. Multipotent mesenchymal stromal cells and the innate immune system. Nat Rev Immunol. 2012;12:383-96.

22. Moll G, Hoogduijn MJ, Ankrum JA. Editorial: Safety, efficacy and mechanisms of action of mesenchymal stem cell therapies. Front Immunol. 2020;11:243.

23. Nauta AJ, Fibbe WE. Immunomodulatory properties of mesenchymal stromal cells. Blood. 2007;110:3499-506.

24. Klyushnenkova E, Mosca JD, Zernetkina V, Majumdar MK, Beggs KJ, Simonetti DW, et al. T cell responses to allogeneic human mesenchymal stem cells: immunogenicity, tolerance, and suppression. J Biomed Sci. 2005; 12:47-57.

25. Aggarwal S, Pittenger MF. Human mesenchymal stem cells modulate allogeneic immune cell responses. Blood. 2005;105:1815-22.

26. Le Blanc K, Rasmusson I, Sundberg B, Gotherstrom C, Hassan M, Uzunel M, et al. Treatment of severe acute graft-versus-host disease with third party haploidentical mesenchymal stem cells. Lancet. 2004;363:1439-41.

27. Galipeau J, Sensebe L. Mesenchymal stromal cells: clinical challenges and therapeutic opportunities. Cell Stem Cell. 2018;22:824-33.

28. Guerrouahen BS, Sidahmed H, Al Sulaiti A, Al Khulaifi M, Cugno C. Enhancing mesenchymal stromal cell immunomodulation for treating conditions influenced by the immune system. Stem Cells Int. 2019;2019: 7219297.

29. Pittenger MF, Discher DE, Peault BM, Phinney DG, Hare JM, Caplan Al. Mesenchymal stem cell perspective: cell biology to clinical progress. NPJ Regen Med. 2019:4:22.

30. Moll G, Drzeniek N, Kamhieh-Milz J, Geissler S, Volk HD, Reinke P. MSC therapies for COVID-19: importance of patient coagulopathy, thromboprophylaxis, cell product quality and mode of delivery for treatment safety and efficacy. Front Immunol. 2020:11:1091.

31. Mizukami A, de Abreu Neto MS, Moreira F, Fernandes-Platzgummer A, Huang YF, Milligan W, et al. A fully-closed and automated hollow Fiber bioreactor for clinical-grade manufacturing of human mesenchymal stem/ stromal cells. Stem Cell Rev Rep. 2018;14:141-3.

32. Jossen V, van den Bos C, Eibl R, Eibl D. Manufacturing human mesenchymal stem cells at clinical scale: process and regulatory challenges. Appl Microbiol Biotechnol. 2018;102:3981-94.

33. de Soure AM, Fernandes-Platzgummer A, Moreira F, Lilaia C, Liu SH, Ku CP, et al. Integrated culture platform based on a human platelet lysate supplement for the isolation and scalable manufacturing of umbilical cord matrix-derived mesenchymal stem/stromal cells. J Tissue Eng Regen Med. 2017;11:1630-40.

34. Fernandes-Platzgummer A, Carmelo JG, da Silva CL, Cabral JM. Clinicalgrade manufacturing of therapeutic human mesenchymal stem/stromal cells in microcarrier-based culture systems. Methods Mol Biol. 2016;1416: $375-88$. 
35. Ankrum JA, Ong JF, Karp JM. Mesenchymal stem cells: immune evasive, not immune privileged. Nat Biotechnol. 2014;32:252-60.

36. von Bahr L, Batsis I, Moll G, Hagg M, Szakos A, Sundberg B, et al. Analysis of tissues following mesenchymal stromal cell therapy in humans indicates limited long-term engraftment and no ectopic tissue formation. Stem Cells. 2012;30:1575-8.

37. Galleu A, Riffo-Vasquez Y, Trento C, Lomas C, Dolcetti L, Cheung TS, et al. Apoptosis in mesenchymal stromal cells induces in vivo recipient-mediated immunomodulation. Sci Transl Med. 2017;9(416):eaam7828.

38. Leibacher J, Henschler R. Biodistribution, migration and homing of systemically applied mesenchymal stem/stromal cells. Stem Cell Res Ther. 2016;7:7.

39. Toma C, Wagner WR, Bowry S, Schwartz A, Villanueva F. Fate of cultureexpanded mesenchymal stem cells in the microvasculature: in vivo observations of cell kinetics. Circ Res. 2009;104:398-402.

40. Nemeth K, Leelahavanichkul A, Yuen PS, Mayer B, Parmelee A, Doi K, et al. Bone marrow stromal cells attenuate sepsis via prostaglandin $E(2)$ dependent reprogramming of host macrophages to increase their interleukin-10 production. Nat Med. 2009;15:42-9.

41. Lee RH, Pulin AA, Seo MJ, Kota DJ, Ylostalo J, Larson BL, et al. Intravenous hMSCs improve myocardial infarction in mice because cells embolized in lung are activated to secrete the anti-inflammatory protein TSG-6. Cell Stem Cell. 2009;5:54-63.

42. Kidd S, Spaeth E, Dembinski JL, Dietrich M, Watson K, Klopp A, et al. Direct evidence of mesenchymal stem cell tropism for tumor and wounding microenvironments using in vivo bioluminescent imaging. Stem Cells. 2009; 27:2614-23.

43. Moll G, Rasmusson-Duprez I, von Bahr L, Connolly-Andersen AM, Elgue G, Funke $L$, et al. Are therapeutic human mesenchymal stromal cells compatible with human blood? Stem Cells. 2012;30:1565-74.

44. Caplan H, Olson SD, Kumar A, George M, Prabhakara KS, Wenzel P, et al. Mesenchymal stromal cell therapeutic delivery: translational challenges to clinical application. Front Immunol. 2019;10:1645

45. Yamahara K, Harada K, Ohshima M, Ishikane S, Ohnishi S, Tsuda H, et al. Comparison of angiogenic, cytoprotective, and immunosuppressive properties of human amnion- and chorion-derived mesenchymal stem cells. PLoS One. 2014;9:e88319.

46. Martins L, Martin PK, Han SW. Angiogenic properties of mesenchymal stem cells in a mouse model of limb ischemia. Methods Mol Biol. 2014;1213:147-69.

47. Watt SM, Gullo F, van der Garde M, Markeson D, Camicia R, Khoo CP, et al. The angiogenic properties of mesenchymal stem/stromal cells and their therapeutic potential. Br Med Bull. 2013;108:25-53.

48. Cunha FF, Martins L, Martin PK, Stilhano RS, Han SW. A comparison of the reparative and angiogenic properties of mesenchymal stem cells derived from the bone marrow of BALB/C and C57/BL6 mice in a model of limb ischemia. Stem Cell Res Ther. 2013;4:86.

49. Kim SW, Zhang HZ, Kim CE, An HS, Kim JM, Kim MH. Amniotic mesenchymal stem cells have robust angiogenic properties and are effective in treating hindlimb ischaemia. Cardiovasc Res. 2012;93:525-34.

50. Kim SW, Lee DW, Yu LH, Zhang HZ, Kim CE, Kim JM, et al. Mesenchymal stem cells overexpressing GCP-2 improve heart function through enhanced angiogenic properties in a myocardial infarction model. Cardiovasc Res. 2012;95:495-506.

51. Efimenko A, Starostina E, Kalinina N, Stolzing A. Angiogenic properties of aged adipose derived mesenchymal stem cells after hypoxic conditioning. J Transl Med. 2011;9:10.

52. Trivedi $P$, Hematti P. Derivation and immunological characterization of mesenchymal stromal cells from human embryonic stem cells. Exp Hematol. 2008;36:350-9.

53. Ren G, Rezaee M, Razavi M, Taysir A, Wang J, Thakor AS. Adipose tissuederived mesenchymal stem cells rescue the function of islets transplanted in sub-therapeutic numbers via their angiogenic properties. Cell Tissue Res. 2019;376:353-64

54. Miceli V, Pampalone M, Vella S, Carreca AP, Amico G, Conaldi PG. Comparison of immunosuppressive and angiogenic properties of human amnion-derived mesenchymal stem cells between 2D and 3D culture systems. Stem Cells Int. 2019;2019:7486279.

55. Carvalho MS, Silva JC, Cabral JMS, da Silva CL, Vashishth D. Cultured cellderived extracellular matrices to enhance the osteogenic differentiation and angiogenic properties of human mesenchymal stem/stromal cells. J Tissue Eng Regen Med. 2019;13:1544-58.
56. Wu Q, Fang $T$, Lang $H$, Chen $M$, Shi P, Pang $X$, et al. Comparison of the proliferation, migration and angiogenic properties of human amniotic epithelial and mesenchymal stem cells and their effects on endothelial cells. Int J Mol Med. 2017:39:918-26.

57. Ribot J, Caliaperoumal G, Paquet J, Boisson-Vidal C, Petite H, Anagnostou F. Type 2 diabetes alters mesenchymal stem cell secretome composition and angiogenic properties. J Cell Mol Med. 2017;21:349-63.

58. Ghensi P, Bressan E, Gardin C, Ferroni L, Soldini MC, Mandelli F, et al. The biological properties of OGI surfaces positively act on osteogenic and angiogenic commitment of mesenchymal stem cells. Materials. 2017;10(11): 1321.

59. Wang S, Mundada L, Colomb E, Ohye RG, Si MS. Mesenchymal stem/stromal cells from discarded neonatal sternal tissue: in vitro characterization and angiogenic properties. Stem Cells Int. 2016;2016:5098747.

60. Montemurro T, Vigano M, Ragni E, Barilani M, Parazzi V, Boldrin V, et al. Angiogenic and anti-inflammatory properties of mesenchymal stem cells from cord blood: soluble factors and extracellular vesicles for cell regeneration. Eur J Cell Biol. 2016;95:228-38.

61. Bartaula-Brevik S, Pedersen TO, Finne-Wistrand A, Bolstad Al, Mustafa K. Angiogenic and immunomodulatory properties of endothelial and mesenchymal stem cells. Tissue Eng A. 2016;22:244-52.

62. Smadja DM, Levy M, Huang L, Rossi E, Blandinieres A, Israel-Biet D, et al. Treprostinil indirectly regulates endothelial colony forming cell angiogenic properties by increasing VEGF-A produced by mesenchymal stem cells. Thromb Haemost. 2015;114:735-47.

63. Kwon S, Ki SM, Park SE, Kim MJ, Hyung B, Lee NK, et al. Anti-apoptotic effects of human Wharton's jelly-derived mesenchymal stem cells on skeletal muscle cells mediated via secretion of XCL1. Mol Ther. 2016;24: 1550-60.

64. Okazaki T, Magaki T, Takeda M, Kajiwara Y, Hanaya R, Sugiyama K, et al. Intravenous administration of bone marrow stromal cells increases survivin and $\mathrm{BCl}-2$ protein expression and improves sensorimotor function following ischemia in rats. Neurosci Lett. 2008;430:109-14.

65. Togel F, Weiss K, Yang Y, Hu Z, Zhang P, Westenfelder C. Vasculotropic, paracrine actions of infused mesenchymal stem cells are important to the recovery from acute kidney injury. American Journal of Physiology. Ren Physiol 2007;292:F1626-F1635.

66. Rehman J, Traktuev D, Li J, Merfeld-Clauss S, Temm-Grove CJ, Bovenkerk JE, et al. Secretion of angiogenic and antiapoptotic factors by human adipose stromal cells. Circulation. 2004;109:1292-8.

67. Bai L, Lennon DP, Caplan Al, DeChant A, Hecker J, Kranso J, et al. Hepatocyte growth factor mediates mesenchymal stem cell-induced recovery in multiple sclerosis models. Nat Neurosci. 2012;15:862-70.

68. Kim J, Hematti P. Mesenchymal stem cell-educated macrophages: a novel type of alternatively activated macrophages. Exp Hematol. 2009;37:1445-53.

69. Sato K, Ozaki K, Oh I, Meguro A, Hatanaka K, Nagai T, et al. Nitric oxide plays a critical role in suppression of T-cell proliferation by mesenchymal stem cells. Blood. 2007;109:228-34.

70. Ramasamy R, Fazekasova H, Lam EW, Soeiro I, Lombardi G, Dazzi F. Mesenchymal stem cells inhibit dendritic cell differentiation and function by preventing entry into the cell cycle. Transplantation. 2007;83:71-6.

71. Ortiz LA, Dutreil M, Fattman C, Pandey AC, Torres G, Go K, et al. Interleukin 1 receptor antagonist mediates the antiinflammatory and antifibrotic effect of mesenchymal stem cells during lung injury. Proc Natl Acad Sci U S A. 2007; 104:11002-7.

72. Nasef A, Chapel A, Mazurier C, Bouchet S, Lopez M, Mathieu N, et al. Identification of IL-10 and TGF-beta transcripts involved in the inhibition of T-lymphocyte proliferation during cell contact with human mesenchymal stem cells. Gene Expr. 2007:13:217-26.

73. Djouad F, Charbonnier LM, Bouffi C, Louis-Plence P, Bony C, Apparailly F, et al. Mesenchymal stem cells inhibit the differentiation of dendritic cells through an interleukin-6-dependent mechanism. Stem Cells. 2007;25:2025-32.

74. Ullah M, Liu DD, Thakor AS. Mesenchymal stromal cell homing: mechanisms and strategies for improvement. iScience. 2019;15:421-38.

75. Honczarenko M, Le Y, Swierkowski M, Ghiran I, Glodek AM, Silberstein LE. Human bone marrow stromal cells express a distinct set of biologically functional chemokine receptors. Stem Cells. 2006;24:1030-41.

76. Von Luttichau I, Notohamiprodjo M, Wechselberger A, Peters C, Henger A, Seliger $C$, et al. Human adult CD34- progenitor cells functionally express the chemokine receptors CCR1, CCR4, CCR7, CXCR5, and CCR10 but not CXCR4. Stem Cells Dev. 2005;14:329-36. 
77. Hocking AM. The role of chemokines in mesenchymal stem cell homing to wounds. Adv Wound Care. 2015;4:623-30.

78. Bartholomew A, Sturgeon C, Siatskas M, Ferrer K, Mclntosh K, Patil S, et al. Mesenchymal stem cells suppress lymphocyte proliferation in vitro and prolong skin graft survival in vivo. Exp Hematol. 2002;30:42-8.

79. Krampera M, Glennie S, Dyson J, Scott D, Laylor R, Simpson E, et al. Bone marrow mesenchymal stem cells inhibit the response of naive and memory antigen-specific T cells to their cognate peptide. Blood. 2003;101:3722-9.

80. Casiraghi F, Azzollini N, Cassis P, Imberti B, Morigi M, Cugini D, et al. Pretransplant infusion of mesenchymal stem cells prolongs the survival of a semiallogeneic heart transplant through the generation of regulatory $T$ cells. J Immunol. 2008;181:3933-46.

81. Tse WT, Pendleton JD, Beyer WM, Egalka MC, Guinan EC. Suppression of allogeneic T-cell proliferation by human marrow stromal cells: implications in transplantation. Transplantation. 2003;75:389-97.

82. Popp FC, Eggenhofer E, Renner P, Slowik P, Lang SA, Kaspar H, et al. Mesenchymal stem cells can induce long-term acceptance of solid organ allografts in synergy with low-dose mycophenolate. Transpl Immunol. 2008; 20:55-60.

83. Liechty KW, MacKenzie TC, Shaaban AF, Radu A, Moseley AM, Deans R, et al. Human mesenchymal stem cells engraft and demonstrate site-specific differentiation after in utero transplantation in sheep. Nat Med. 2000;6:1282-6.

84. Nasef A, Mathieu N, Chapel A, Frick J, Francois S, Mazurier C, et al. Immunosuppressive effects of mesenchymal stem cells: involvement of HLA-G. Transplantation. 2007:84:231-7.

85. Morelli AE, Thomson AW. Tolerogenic dendritic cells and the quest for transplant tolerance. Nat Rev Immunol. 2007;7:610-21.

86. Magatti M, Stefani FR, Papait A, Cargnoni A, Masserdotti A, Silini AR, et al. Perinatal mesenchymal stromal cells and their possible contribution to fetalmaternal tolerance. Cells. 2019;8(11):1401.

87. Nouri-Shirazi M. Dendritic cells in transplant tolerance. Iran J Immunol. 2007; 4:1-14.

88. Jiang XX, Zhang Y, Liu B, Zhang SX, Wu Y, Yu XD, et al. Human mesenchymal stem cells inhibit differentiation and function of monocytederived dendritic cells. Blood. 2005;105:4120-6.

89. Nauta AJ, Kruisselbrink AB, Lurvink E, Willemze R, Fibbe WE. Mesenchymal stem cells inhibit generation and function of both CD34+-derived and monocyte-derived dendritic cells. J Immunol. 2006;177:2080-7.

90. Abomaray FM, Al Jumah MA, Kalionis B, AlAskar AS, Al Harthy S, Jawdat D, et al. Human chorionic villous mesenchymal stem cells modify the functions of human dendritic cells, and induce an anti-inflammatory phenotype in CD1+ dendritic cells. Stem Cell Rev Rep. 2015;11:423-41.

91. Reis M, Mavin E, Nicholson L, Green K, Dickinson AM, Wang XN. Mesenchymal stromal cell-derived extracellular vesicles attenuate dendritic cell maturation and function. Front Immunol. 2018;9:2538.

92. Abel AM, Yang C, Thakar MS, Malarkannan S. Natural killer cells: development, maturation, and clinical utilization. Front Immunol. 2018;9: 1869.

93. Fu Q, Man X, Yu M, Chu Y, Luan X, Piao H, et al. Human decidua mesenchymal stem cells regulate decidual natural killer cell function via interactions between collagen and leukocyteassociated immunoglobulinlike receptor 1. Mol Med Rep. 2017;16:2791-8.

94. Vacca P, Vitale C, Montaldo E, Conte R, Cantoni C, Fulcheri E, et al. CD34+ hematopoietic precursors are present in human decidua and differentiate into natural killer cells upon interaction with stromal cells. Proc Natl Acad Sci U S A. 2011;108:2402-7.

95. Spaggiari GM, Capobianco A, Becchetti S, Mingari MC, Moretta L. Mesenchymal stem cell-natural killer cell interactions: evidence that activated NK cells are capable of killing MSCs, whereas MSCs can inhibit IL2-induced NK-cell proliferation. Blood. 2006;107:1484-90.

96. Najar M, Fayyad-Kazan M, Meuleman N, Bron D, Fayyad-Kazan H, Lagneaux L. Immunomodulatory effects of foreskin mesenchymal stromal cells on natural killer cells. J Cell Physiol. 2018;233:5243-54.

97. Najar M, Fayyad-Kazan M, Meuleman N, Bron D, Fayyad-Kazan H, Lagneaux L. Mesenchymal stromal cells of the bone marrow and natural killer cells: cell interactions and cross modulation. J Cell Commun Signal. 2018;12:673-88.

98. Gotherstrom C, Lundqvist A, Duprez IR, Childs R, Berg L, le Blanc K. Fetal and adult multipotent mesenchymal stromal cells are killed by different pathways. Cytotherapy. 2011;13:269-78.

99. Spaggiari GM, Capobianco A, Abdelrazik H, Becchetti F, Mingari MC, Moretta L. Mesenchymal stem cells inhibit natural killer-cell proliferation, cytotoxicity, and cytokine production: role of indoleamine 2,3-dioxygenase and prostaglandin E2. Blood. 2008;111:1327-33.

100. Michelo CM, Fasse E, van Cranenbroek B, Linda K, van der Meer A, Abdelrazik $\mathrm{H}$, et al. Added effects of dexamethasone and mesenchymal stem cells on early natural killer cell activation. Transpl Immunol. 2016;37:1-9.

101. Najar M, Fayyad-Kazan M, Merimi M, Burny A, Bron D, Fayyad-Kazan H, et al. Mesenchymal stromal cells and natural killer cells: a complex story of love and hate. Curr Stem Cell Res Ther. 2019;14:14-21.

102. Najar M, Bouhtit F, Melki R, Afif H, Hamal A, Fahmi H, et al. Mesenchymal stromal cell-based therapy: new perspectives and challenges. J Clin Med. 2019;8(5):626.

103. Giuliani M, Bennaceur-Griscelli A, Nanbakhsh A, Oudrhiri N, Chouaib S, Azzarone $B$, et al. TLR ligands stimulation protects MSC from NK killing. Stem Cells. 2014;32:290-300.

104. Bernardo ME, Fibbe WE. Mesenchymal stromal cells: sensors and switchers of inflammation. Cell Stem Cell. 2013;13:392-402.

105. Glass CK, Natoli G. Molecular control of activation and priming in macrophages. Nat Immunol. 2016;17:26-33.

106. Gustafsson C, Mjosberg J, Matussek A, Geffers R, Matthiesen L, Berg G, et al. Gene expression profiling of human decidual macrophages: evidence for immunosuppressive phenotype. PLoS One. 2008;3:e2078.

107. Mantovani A, Sica A, Sozzani S, Allavena P, Vecchi A, Locati M. The chemokine system in diverse forms of macrophage activation and polarization. Trends Immunol. 2004;25:677-86.

108. Li W, Zhang Q, Wang M, Wu H, Mao F, Zhang B, et al. Macrophages are involved in the protective role of human umbilical cord-derived stromal cells in renal ischemia-reperfusion injury. Stem Cell Res. 2013;10:405-16.

109. Magatti M, Vertua E, De Munari S, Caro M, Caruso M, Silini A, et al. Human amnion favours tissue repair by inducing the M1-to-M2 switch and enhancing M2 macrophage features. J Tissue Eng Regen Med. 2017;11: 2895-911.

110. Negi N, Griffin MD. Effects of mesenchymal stromal cells on regulatory T cells: current understanding and clinical relevance. Stem Cells. 2020;38:596-605.

111. Akiyama K, Chen C, Wang D, Xu X, Qu C, Yamaza T, et al. Mesenchymalstem-cell-induced immunoregulation involves FAS-ligand-/FAS-mediated T cell apoptosis. Cell Stem Cell. 2012;10:544-55.

112. Chinnadurai R, Copland IB, Garcia MA, Petersen CT, Lewis CN, Waller EK, et al. Cryopreserved mesenchymal stromal cells are susceptible to T-cell mediated apoptosis which is partly rescued by IFNgamma licensing. Stem Cells. 2016;34:2429-42.

113. Di Nicola M, Carlo-Stella C, Magni M, Milanesi M, Longoni PD, Matteucci P, et al. Human bone marrow stromal cells suppress T-lymphocyte proliferation induced by cellular or nonspecific mitogenic stimuli. Blood. 2002;99:3838-43.

114. Putra A, Ridwan FB, Putridewi Al, Kustiyah AR, Wirastuti K, Sadyah NAC, et al. The role of TNF-alpha induced MSCs on suppressive inflammation by increasing TGF-beta and IL-10. Open Access Macedonian J Med Sci. 2018;6: 1779-83.

115. Jin P, Zhao Y, Liu H, Chen J, Ren J, Jin J, et al. Interferon-gamma and tumor necrosis factor-alpha polarize bone marrow stromal cells uniformly to a Th1 phenotype. Sci Rep. 2016;6:26345.

116. Polchert D, Sobinsky J, Douglas G, Kidd M, Moadsiri A, Reina E, et al. IFNgamma activation of mesenchymal stem cells for treatment and prevention of graft versus host disease. Eur J Immunol. 2008;38:1745-55.

117. Mbongue JC, Nicholas DA, Torrez TW, Kim NS, Firek AF, Langridge WH. The role of Indoleamine 2, 3-dioxygenase in immune suppression and autoimmunity. Vaccines. 2015;3:703-29.

118. Terness P, Bauer TM, Rose L, Dufter C, Watzlik A, Simon H, et al. Inhibition of allogeneic $T$ cell proliferation by indoleamine 2,3-dioxygenase-expressing dendritic cells: mediation of suppression by tryptophan metabolites. J Exp Med. 2002;196:447-57.

119. Pevsner-Fischer M, Morad V, Cohen-Sfady M, Rousso-Noori L, Zanin-Zhorov A, Cohen S, et al. Toll-like receptors and their ligands control mesenchymal stem cell functions. Blood. 2007;109:1422-32.

120. Wang Y, Chen X, Cao W, Shi Y. Plasticity of mesenchymal stem cells in immunomodulation: pathological and therapeutic implications. Nat Immunol. 2014;15:1009-16.

121. Liotta F, Angeli R, Cosmi L, Fili L, Manuelli C, Frosali F, et al. Toll-like receptors 3 and 4 are expressed by human bone marrow-derived mesenchymal stem cells and can inhibit their T-cell modulatory activity by impairing Notch signaling. Stem Cells. 2008;26:279-89. 
122. Zanin-Zhorov A, Tal-Lapidot G, Cahalon L, Cohen-Sfady M, Pevsner-Fischer M, Lider O, et al. Cutting edge: T cells respond to lipopolysaccharide innately via TLR4 signaling. J Immunol. 2007;179:41-4.

123. Hwa Cho H, Bae YC, Jung JS. Role of toll-like receptors on human adiposederived stromal cells. Stem Cells. 2006;24:2744-52.

124. Franquesa M, Mensah FK, Huizinga R, Strini T, Boon L, Lombardo E, et al. Human adipose tissue-derived mesenchymal stem cells abrogate plasmablast formation and induce regulatory B cells independently of T helper cells. Stem Cells. 2015;33:880-91.

125. Corcione A, Benvenuto F, Ferretti E, Giunti D, Cappiello V, Cazzanti F, et al. Human mesenchymal stem cells modulate B-cell functions. Blood. 2006;107; 367-72.

126. van de Veen W, Stanic B, Wirz OF, Jansen K, Globinska A, Akdis M. Role of regulatory $B$ cells in immune tolerance to allergens and beyond. J Allergy Clin Immunol. 2016;138:654-65.

127. Rosado MM, Bernardo ME, Scarsella M, Conforti A, Giorda E, Biagini S, et al. Inhibition of B-cell proliferation and antibody production by mesenchymal stromal cells is mediated by T cells. Stem Cells Dev. 2015;24:93-103.

128. Feng X, Che N, Liu Y, Chen H, Wang D, Li X, et al. Restored immunosuppressive effect of mesenchymal stem cells on B cells after olfactory 1/early B cell factor-associated zinc-finger protein down-regulation in patients with systemic lupus erythematosus. Arthritis Rheumatol. 2014;66: 3413-23.

129. Wang M, Yuan Q, Xie L. Mesenchymal stem cell-based immunomodulation: properties and clinical application. Stem Cells Int. 2018;2018:3057624.

130. Traggiai E, Volpi S, Schena F, Gattorno M, Ferlito F, Moretta L, et al. Bone marrow-derived mesenchymal stem cells induce both polyclonal expansion and differentiation of B cells isolated from healthy donors and systemic lupus erythematosus patients. Stem Cells. 2008:26:562-9.

131. Rasmusson I, Le Blanc K, Sundberg B, Ringden O. Mesenchymal stem cells stimulate antibody secretion in human B cells. Scand I Immunol. 2007;65: 336-43.

132. Poggi A, Zocchi MR. Immunomodulatory properties of mesenchymal stromal cells: still unresolved "Yin and Yang". Curr Stem Cell Res Ther. 2019; 14:344-50.

133. Fan XL, Zhang Y, Li X, Fu QL. Mechanisms underlying the protective effects of mesenchymal stem cell-based therapy. Cell Mol Life Sci. 2020;77:2771-94.

134. De Becker A, Riet IV. Homing and migration of mesenchymal stromal cells: how to improve the efficacy of cell therapy? World J Stem Cells. 2016;8:73-87.

135. Sackstein R, Merzaban JS, Cain DW, Dagia NM, Spencer JA, Lin CP, et al. Ex vivo glycan engineering of CD44 programs human multipotent mesenchymal stromal cell trafficking to bone. Nat Med. 2008;14:181-7.

136. Sordi V. Mesenchymal stem cell homing capacity. Transplantation. 2009;87: S42-5.

137. Karp JM, Leng Teo GS. Mesenchymal stem cell homing: the devil is in the details. Cell Stem Cell. 2009:4:206-16.

138. Suila H, Hirvonen T, Kotovuori A, Ritamo I, Kerkela E, Anderson H, et al. Human umbilical cord blood-derived mesenchymal stromal cells display a novel interaction between P-selectin and galectin-1. Scand J Immunol. 2014;80:12-21.

139. Bailey AM, Lawrence MB, Shang H, Katz AJ, Peirce SM. Agent-based model of therapeutic adipose-derived stromal cell trafficking during ischemia predicts ability to roll on P-selectin. PLoS Comput Biol. 2009;5:e1000294.

140. Bonaros N, Sondermeijer H, Wiedemann D, Schlechta B, Schachner T, Schuster M, et al. Downregulation of the CXC chemokine receptor 4/ stromal cell-derived factor 1 pathway enhances myocardial neovascularization, cardiomyocyte survival, and functional recovery after myocardial infarction. J Thorac Cardiovasc Surg. 2011;142:687-96 96 e1-2.

141. Ip JE, Wu Y, Huang J, Zhang L, Pratt RE, Dzau VJ. Mesenchymal stem cells use integrin beta1 not CXC chemokine receptor 4 for myocardial migration and engraftment. Mol Biol Cell. 2007;18:2873-82.

142. Cencioni C, Capogrossi MC, Napolitano M. The SDF-1/CXCR4 axis in stem cell preconditioning. Cardiovasc Res. 2012;94:400-7.

143. Lau TT, Wang DA. Stromal cell-derived factor-1 (SDF-1): homing factor for engineered regenerative medicine. Expert Opin Biol Ther. 2011:11:189-97.

144. Zhang D, Fan GC, Zhou X, Zhao T, Pasha Z, Xu M, et al. Over-expression of CXCR4 on mesenchymal stem cells augments myoangiogenesis in the infarcted myocardium. J Mol Cell Cardiol. 2008:44:281-92.

145. Segers VF, Van Riet I, Andries LJ, Lemmens K, Demolder MJ, De Becker AJ, et al. Mesenchymal stem cell adhesion to cardiac microvascular endothelium: activators and mechanisms. American Journal of Physiology. Heart Circ Physiol 2006;290:H1370-H1377.

146. Chang CF, Lee MW, Kuo PY, Wang YJ, Tu YH, Hung SC. Three-dimensional collagen fiber remodeling by mesenchymal stem cells requires the integrinmatrix interaction. Journal of biomedical materials research. Part A 2007;80: $466-474$.

147. Monaco S, Sparano V, Gioia M, Sbardella D, Di Pierro D, Marini S, et al. Enzymatic processing of collagen IV by MMP-2 (gelatinase A) affects neutrophil migration and it is modulated by extracatalytic domains. Protein Sci. 2006;15:2805-15.

148. Steingen C, Brenig F, Baumgartner L, Schmidt J, Schmidt A, Bloch W. Characterization of key mechanisms in transmigration and invasion of mesenchymal stem cells. J Mol Cell Cardiol. 2008;44:1072-84.

149. Toth M, Sohail A, Fridman R. Assessment of gelatinases (MMP-2 and MMP-9) by gelatin zymography. Methods Mol Biol. 2012;878:121-35.

150. Son BR, Marquez-Curtis LA, Kucia M, Wysoczynski M, Turner AR, Ratajczak J, et al. Migration of bone marrow and cord blood mesenchymal stem cells in vitro is regulated by stromal-derived factor-1-CXCR4 and hepatocyte growth factor-c-met axes and involves matrix metalloproteinases. Stem Cells. 2006;24:1254-64.

151. Zhao H, Bernardo MM, Osenkowski P, Sohail A, Pei D, Nagase H, et al. Differential inhibition of membrane type 3 (MT3)-matrix metalloproteinase (MMP) and MT1-MMP by tissue inhibitor of metalloproteinase (TIMP)-2 and TIMP-3 rgulates pro-MMP-2 activation. J Biol Chem. 2004;279:8592-601.

152. George MJ, Prabhakara K, Toledano-Furman NE, Wang YW, Gill BS, Wade CE, et al. Clinical cellular therapeutics accelerate clot formation. Stem Cells Transl Med. 2018;7:731-9.

153. Moll G, Ignatowicz L, Catar R, Luecht C, Sadeghi B, Hamad O, et al. Different procoagulant activity of therapeutic mesenchymal stromal cells derived from bone marrow and placental decidua. Stem Cells Dev. 2015;24:2269-79.

154. Moll G, Jitschin R, von Bahr L, Rasmusson-Duprez I, Sundberg B, Lonnies L, et al. Mesenchymal stromal cells engage complement and complement receptor bearing innate effector cells to modulate immune responses. PLoS One. 2011;6:e21703.

155. Ferrara JL, Levine JE, Reddy P, Holler E. Graft-versus-host disease. Lancet. 2009:373:1550-61

156. Westin JR, Saliba RM, De Lima M, Alousi A, Hosing C, Qazilbash MH, et al. Steroid-refractory acute GVHD: predictors and outcomes. Adv Hematol. 2011;2011:601953

157. Paczesny S, Krijanovski Ol, Braun TM, Choi SW, Clouthier SG, Kuick R, et al. A biomarker panel for acute graft-versus-host disease. Blood. 2009;113:273-8.

158. Paczesny S, Choi SW, Ferrara JL. Acute graft-versus-host disease: new treatment strategies. Curr Opin Hematol. 2009;16:427-36.

159. Kurtzberg J, Prockop S, Chaudhury S, Horn B, Nemecek E, Prasad V, et al. Study 275: updated expanded access program for remestemcel-L in steroidrefractory acute graft-versus-host disease in children. Biol Blood Marrow Transplant. 2020;26:855-64.

160. Kurtzberg J, Abdel-Azim H, Carpenter P, Chaudhury S, Horn B, Mahadeo K, et al. A phase 3, single-arm, prospective study of remestemcel-L, ex vivo culture-expanded adult human mesenchymal stromal cells for the treatment of pediatric patients who failed to respond to steroid treatment for acute graft-versus-host disease. Biol Blood Marrow Transplant. 2020;26: $845-54$.

161. Kebriaei P, Hayes J, Daly A, Uberti J, Marks DI, Soiffer R, et al. A phase 3 randomized study of remestemcel-L versus placebo added to second-line therapy in patients with steroid-refractory acute graft-versus-host disease. Biol Blood Marrow Transplant. 2020;26:835-44.

162. Galipeau J. Mesenchymal stromal cells for graft-versus-host disease: a trilogy. Biol Blood Marrow Transplant. 2020;26:e89-91.

163. Locatelli F, Algeri M, Trevisan V, Bertaina A. Remestemcel-L for the treatment of graft versus host disease. Expert Rev Clin Immunol. 2017;13: $43-56$.

164. Sobrado CW, Leal RF, Sobrado LF. Therapies for Crohn's disease: a clinical update. Arq Gastroenterol. 2016;53:206-11.

165. Ha F, Khalil H. Crohn's disease: a clinical update. Ther Adv Gastroenterol. 2015;8:352-9.

166. Baumgart DC, Sandborn WJ. Crohn's disease. Lancet. 2012;380:1590-605.

167. Garcia-Bosch O, Ricart E, Panes J. Review article: stem cell therapies for inflammatory bowel disease - efficacy and safety. Aliment Pharmacol Ther. 2010;32:939-52. 
168. Copelan EA. Hematopoietic stem-cell transplantation. N Engl J Med. 2006; 354:1813-26.

169. Liew A, O'Brien T, Egan L. Mesenchymal stromal cell therapy for Crohn's disease. Dig Dis. 2014;32(Suppl 1):50-60

170. Barnhoorn MC, Van Halteren AGS, Van Pel M, Molendijk I, Struijk AC, Jansen PM, et al. Lymphoproliferative disease in the rectum 4 years after local mesenchymal stromal cell therapy for refractory perianal Crohn's fistulas: a case report. J Crohns Colitis. 2019;13:807-11.

171. Hommes DW, Duijvestein M, Zelinkova Z, Stokkers PC, Ley MH, Stoker J, et al. Long-term follow-up of autologous hematopoietic stem cell transplantation for severe refractory Crohn's disease. J Crohns Colitis. 2011;5: 543-9.

172. Barnhoorn MC, Wasser M, Roelofs H, Maljaars PWJ, Molendijk I, Bonsing BA, et al. Long-term evaluation of allogeneic bone marrow-derived mesenchymal stromal cell therapy for Crohn's disease perianal fistulas. J Crohns Colitis. 2020;14:64-70

173. Duijvestein M, Vos AC, Roelofs H, Wildenberg ME, Wendrich BB, Verspaget $\mathrm{HW}$, et al. Autologous bone marrow-derived mesenchymal stromal cell treatment for refractory luminal Crohn's disease: results of a phase I study. Gut. 2010;59:1662-9.

174. Forbes GM, Sturm MJ, Leong RW, Sparrow MP, Segarajasingam D, Cummins AG, et al. A phase 2 study of allogeneic mesenchymal stromal cells for luminal Crohn's disease refractory to biologic therapy. Clin Gastroenterol Hepatol. 2014;12:64-71.

175. Forbes GM. Mesenchymal stromal cell therapy in Crohn's disease. Dig Dis. 2017;35:115-22.

176. Gregoire C, Briquet A, Pirenne C, Lechanteur C, Louis E, Beguin Y. Allogeneic mesenchymal stromal cells for refractory luminal Crohn's disease: a phase III study. Dig Liver Dis. 2018;50:1251-5.

177. Panes J, Garcia-Olmo D, Van Assche G, Colombel JF, Reinisch W, Baumgart DC, et al. Long-term efficacy and safety of stem cell therapy (Cx601) for complex perianal fistulas in patients with Crohn's disease. Gastroenterology. 2018;154:1334-42 e4.

178. Panes J, Garcia-Olmo D, Van Assche G, Colombel JF, Reinisch W, Baumgart DC, et al. Expanded allogeneic adipose-derived mesenchymal stem cells (Cx601) for complex perianal fistulas in Crohn's disease: a phase 3 randomised, double-blind controlled trial. Lancet. 2016;388:1281-90.

179. Collaborators GBDD. Health effects of dietary risks in 195 countries, 19902017: a systematic analysis for the Global Burden of Disease Study 2017. Lancet. 2019;393:1958-72.

180. Collaborators GBDS. Global, regional, and national burden of stroke, 19902016: a systematic analysis for the Global Burden of Disease Study 2016. Lancet Neurol. 2019;18:439-58.

181. Collaborators GBDSC. The global, regional, and national burden of stomach cancer in 195 countries, 1990-2017: a systematic analysis for the Global Burden of Disease study 2017. Lancet Gastroenterol Hepatol. 2020;5:42-54.

182. Meier T, Grafe K, Senn F, Sur P, Stangl Gl, Dawczynski C, et al. Cardiovascular mortality attributable to dietary risk factors in 51 countries in the WHO European region from 1990 to 2016: a systematic analysis of the Global Burden of Disease Study. Eur J Epidemiol. 2019;34:37-55.

183. Cahill TJ, Choudhury RP, Riley PR. Heart regeneration and repair after myocardial infarction: translational opportunities for novel therapeutics. Nat Rev Drug Discov. 2017;16:699-717.

184. Talman V, Ruskoaho H. Cardiac fibrosis in myocardial infarction-from repair and remodeling to regeneration. Cell Tissue Res. 2016;365:563-81.

185. Quevedo HC, Hatzistergos KE, Oskouei BN, Feigenbaum GS, Rodriguez JE, Valdes $\mathrm{D}$, et al. Allogeneic mesenchymal stem cells restore cardiac function in chronic ischemic cardiomyopathy via trilineage differentiating capacity. Proc Natl Acad Sci U S A. 2009;106:14022-7.

186. Qi CM, Ma GS, Liu NF, Shen CX, Chen Z, Liu XJ, et al. Transplantation of magnetically labeled mesenchymal stem cells improves cardiac function in a swine myocardial infarction model. Chin Med J. 2008;121: 544-50.

187. Zhang M, Mal N, Kiedrowski M, Chacko M, Askari AT, Popovic ZB, et al. SDF1 expression by mesenchymal stem cells results in trophic support of cardiac myocytes after myocardial infarction. FASEB J. 2007;21:3197-207.

188. Amado LC, Saliaris AP, Schuleri KH, St John M, Xie JS, Cattaneo S, et al. Cardiac repair with intramyocardial injection of allogeneic mesenchymal stem cells after myocardial infarction. Proc Natl Acad Sci U S A. 2005;102: 11474-9.
189. Toma C, Pittenger MF, Cahill KS, Byrne BJ, Kessler PD. Human mesenchymal stem cells differentiate to a cardiomyocyte phenotype in the adult murine heart. Circulation. 2002;105:93-8.

190. Velagapudi P, Turagam M, Kolte D, Khera S, Hyder O, Gordon P, et al. Intramyocardial autologous CD34+ cell therapy for refractory angina: a meta-analysis of randomized controlled trials. Cardiovasc Revasc Med. 2019; 20:215-9.

191. Ishigami S, Ohtsuki S, Tarui S, Ousaka D, Eitoku T, Kondo M, et al. Intracoronary autologous cardiac progenitor cell transfer in patients with hypoplastic left heart syndrome: the TICAP prospective phase 1 controlled trial. Circ Res. 2015;116:653-64.

192. Selem SM, Kaushal S, Hare JM. Stem cell therapy for pediatric dilated cardiomyopathy. Curr Cardiol Rep. 2013;15:369.

193. Losordo DW, Henry TD, Davidson C, Sup Lee J, Costa MA, Bass T, et al. Intramyocardial, autologous CD34+ cell therapy for refractory angina. Circ Res. 2011;109:428-36.

194. Chen SL, Fang WW, Ye F, Liu YH, Qian J, Shan SJ, et al. Effect on left ventricular function of intracoronary transplantation of autologous bone marrow mesenchymal stem cell in patients with acute myocardial infarction. Am J Cardiol. 2004;94:92-5.

195. Braunwald $E$. The war against heart failure: the Lancet lecture. Lancet. 2015; $385: 812-24$

196. Vivien CJ, Hudson JE, Porrello ER. Evolution, comparative biology and ontogeny of vertebrate heart regeneration. NPJ Regen Med. 2016;1:16012.

197. Kloner RA. Current state of clinical translation of cardioprotective agents for acute myocardial infarction. Circ Res. 2013;113:451-63.

198. Perin EC, Sanz-Ruiz R, Sanchez PL, Lasso J, Perez-Cano R, Alonso-Farto JC, et al. Adipose-derived regenerative cells in patients with ischemic cardiomyopathy: the PRECISE trial. Am Heart J. 2014;168:88-95 e2.

199. Karantalis V, DiFede DL, Gerstenblith G, Pham S, Symes J, Zambrano JP, et al. Autologous mesenchymal stem cells produce concordant improvements in regional function, tissue perfusion, and fibrotic burden when administered to patients undergoing coronary artery bypass grafting: the Prospective Randomized Study of Mesenchymal Stem Cell Therapy in Patients Undergoing Cardiac Surgery (PROMETHEUS) trial. Circ Res. 2014;114: 1302-10.

200. Heldman AW, Difede DL, Fishman JE, Zambrano JP, Trachtenberg BH, Karantalis $\mathrm{V}$, et al. Transendocardial mesenchymal stem cells and mononuclear bone marrow cells for ischemic cardiomyopathy: the TAC-HFT randomized trial. JAMA. 2014;311:62-73.

201. Qayyum AA, Haack-Sorensen M, Mathiasen AB, Jorgensen E, Ekblond A, Kastrup J. Adipose-derived mesenchymal stromal cells for chronic myocardial ischemia (MyStromalCell Trial): study design. Regen Med. 2012;7: 421-8.

202. Hare JM, Fishman JE, Gerstenblith G, DiFede Velazquez DL, Zambrano JP, Suncion VY, et al. Comparison of allogeneic vs autologous bone marrowderived mesenchymal stem cells delivered by transendocardial injection in patients with ischemic cardiomyopathy: the POSEIDON randomized trial. JAMA. 2012;308:2369-79.

203. Schuleri KH, Feigenbaum GS, Centola M, Weiss ES, Zimmet JM, Turney J, et al. Autologous mesenchymal stem cells produce reverse remodelling in chronic ischaemic cardiomyopathy. Eur Heart J. 2009;30:2722-32.

204. Karantalis V, Hare JM. Use of mesenchymal stem cells for therapy of cardiac disease. Circ Res. 2015;116:1413-30.

205. Friis T, Haack-Sorensen M, Mathiasen AB, Ripa RS, Kristoffersen US, Jorgensen $\mathrm{E}$, et al. Mesenchymal stromal cell derived endothelial progenitor treatment in patients with refractory angina. Scand Cardiovasc J. 2011;45: 161-8.

206. Bartunek J, Davison B, Sherman W, Povsic T, Henry TD, Gersh B, et al. Congestive heart failure Cardiopoietic regenerative therapy (CHART-1) trial design. Eur J Heart Fail. 2016;18:160-8.

207. Teerlink JR, Metra M, Filippatos GS, Davison BA, Bartunek J, Terzic A, et al. Benefit of cardiopoietic mesenchymal stem cell therapy on left ventricular remodelling: results from the Congestive Heart Failure Cardiopoietic Regenerative Therapy (CHART-1) study. Eur J Heart Fail. 2017;19:1520-9.

208. Kouroupis D, Sanjurjo-Rodriguez C, Jones E, Correa D. Mesenchymal stem cell functionalization for enhanced therapeutic applications. Tissue Eng Part B Rev. 2019;25:55-77.

209. Moulton VR, Suarez-Fueyo A, Meidan E, Li H, Mizui M, Tsokos GC. Pathogenesis of human systemic lupus erythematosus: a cellular perspective. Trends Mol Med. 2017;23:615-35. 
210. Couture J, Silverman ED. Update on the pathogenesis and treatment of childhood-onset systemic lupus erythematosus. Curr Opin Rheumatol. 2016; 28:488-96.

211. Ahmadpoor P, Dalili N, Rostami M. An update on pathogenesis of systemic lupus erythematosus. Iran J Kidney Dis. 2014;8:171-84.

212. Choi J, Kim ST, Craft J. The pathogenesis of systemic lupus erythematosusan update. Curr Opin Immunol. 2012;24:651-7.

213. Atta AM, Santiago MB, Guerra FG, Pereira MM, Sousa Atta ML. Autoimmune response of IgE antibodies to cellular self-antigens in systemic lupus erythematosus. Int Arch Allergy Immunol. 2010;152:401-6.

214. Fietta P, Fietta P, Delsante G. Psychiatric and neuropsychological manifestations of systemic lupus erythematosus. Acta Biomed. 2011;82:97-114.

215. Cojocaru M, Cojocaru IM, Silosi I, Vrabie CD. Manifestations of systemic lupus erythematosus. Maedica. 2011;6:330-6.

216. Wang D, Zhang $H$, Liang J, Li X, Feng $X$, Wang $H$, et al. Allogeneic mesenchymal stem cell transplantation in severe and refractory systemic lupus erythematosus: 4 years of experience. Cell Transplant. 2013;22:2267-77.

217. Burrack AL, Martinov T, Fife BT. T cell-mediated Beta cell destruction: autoimmunity and alloimmunity in the context of type 1 diabetes. Front Endocrinol. 2017:8:343.

218. Silva DG, Daley SR, Hogan J, Lee SK, Teh CE, Hu DY, et al. Anti-islet autoantibodies trigger autoimmune diabetes in the presence of an increased frequency of islet-reactive CD4 T cells. Diabetes. 2011;60:2102-11.

219. Nair GG, Tzanakakis ES, Hebrok M. Emerging routes to the generation of functional beta-cells for diabetes mellitus cell therapy. Nat Rev Endocrinol. 2020. Online ahead of print.

220. Kalra S, Mukherjee JJ, Venkataraman S, Bantwal G, Shaikh S, Saboo B, et al. Hypoglycemia: the neglected complication. Indian J Endocrinol Metab. 2013;17:819-34.

221. Wu H, Mahato RI. Mesenchymal stem cell-based therapy for type 1 diabetes. Discov Med. 2014;17:139-43.

222. Karaoz E, Okcu A, Unal ZS, Subasi C, Saglam O, Duruksu G. Adipose tissuederived mesenchymal stromal cells efficiently differentiate into insulinproducing cells in pancreatic islet microenvironment both in vitro and in vivo. Cytotherapy. 2013;15:557-70.

223. Mabed M, Shahin M. Mesenchymal stem cell-based therapy for the treatment of type 1 diabetes mellitus. Curr Stem Cell Res Ther. 2012;7:179-90.

224. Cai J, Wu Z, Xu X, Liao L, Chen J, Huang L, et al. Umbilical cord mesenchymal stromal cell with autologous bone marrow cell transplantation in established type 1 diabetes: a pilot randomized controlled open-label clinical study to assess safety and impact on insulin secretion. Diabetes Care. 2016;39:149-57.

225. Urban VS, Kiss J, Kovacs J, Gocza E, Vas V, Monostori E, et al. Mesenchymal stem cells cooperate with bone marrow cells in therapy of diabetes. Stem Cells. 2008;26:244-53.

226. Capkun G, Dahlke F, Lahoz R, Nordstrom B, Tilson HH, Cutter G, et al. Mortality and comorbidities in patients with multiple sclerosis compared with a population without multiple sclerosis: An observational study using the US Department of Defense administrative claims database. Mult Scler Relat Disord. 2015:4:546-54.

227. Thompson AJ, Chandraratna D. Multiple Sclerosis International Federation: stimulating international cooperation in research. Neurology. 2013;81:1793-5.

228. Bai L, Lennon DP, Eaton V, Maier K, Caplan Al, Miller SD, et al. Human bone marrow-derived mesenchymal stem cells induce Th2-polarized immune response and promote endogenous repair in animal models of multiple sclerosis. Glia. 2009;57:1192-203.

229. Zappia E, Casazza S, Pedemonte E, Benvenuto F, Bonanni I, Gerdoni E, et al. Mesenchymal stem cells ameliorate experimental autoimmune encephalomyelitis inducing T-cell anergy. Blood. 2005;106:1755-61.

230. Laroni A, de Rosbo NK, Uccelli A. Mesenchymal stem cells for the treatment of neurological diseases: Immunoregulation beyond neuroprotection. Immunol Lett. 2015;168:183-90.

231. Dulamea A. Mesenchymal stem cells in multiple sclerosis - translation to clinical trials. J Med Life. 2015:8:24-7.

232. Yamout B, Hourani R, Salti H, Barada W, El-Hajj T, Al-Kutoubi A, et al. Bone marrow mesenchymal stem cell transplantation in patients with multiple sclerosis: a pilot study. J Neuroimmunol. 2010;227:185-9.

233. Kassis I, Grigoriadis N, Gowda-Kurkalli B, Mizrachi-Kol R, Ben-Hur T, Slavin S, et al. Neuroprotection and immunomodulation with mesenchymal stem cells in chronic experimental autoimmune encephalomyelitis. Arch Neurol. 2008;65:753-61.
234. Gerdoni E, Gallo B, Casazza S, Musio S, Bonanni I, Pedemonte E, et al. Mesenchymal stem cells effectively modulate pathogenic immune response in experimental autoimmune encephalomyelitis. Ann Neurol. 2007;61:219-27.

235. Connick P, Kolappan M, Crawley C, Webber DJ, Patani R, Michell AW, et al. Autologous mesenchymal stem cells for the treatment of secondary progressive multiple sclerosis: an open-label phase 2a proof-of-concept study. Lancet Neurol. 2012;11:150-6.

236. Elahi FM, Farwell DG, Nolta JA, Anderson JD. Preclinical translation of exosomes derived from mesenchymal stem/stromal cells. Stem Cells. 2020; 38:15-21.

237. Rohde E, Pachler K, Gimona M. Manufacturing and characterization of extracellular vesicles from umbilical cord-derived mesenchymal stromal cells for clinical testing. Cytotherapy. 2019;21:581-92.

238. Xie M, Xiong W, She Z, Wen Z, Abdirahman AS, Wan W, et al. Immunoregulatory effects of stem cell-derived extracellular vesicles on immune cells. Front Immunol. 2020;11:13.

239. Casado-Diaz A, Quesada-Gomez JM, Dorado G. Extracellular vesicles derived from mesenchymal stem cells (MSC) in regenerative medicine: applications in skin wound healing. Front Bioeng Biotechnol. 2020;8:146.

240. Rani S, Ryan AE, Griffin MD, Ritter T. Mesenchymal stem cell-derived extracellular vesicles: toward cell-free therapeutic applications. Mol Ther. 2015;23:812-23.

\section{Publisher's Note}

Springer Nature remains neutral with regard to jurisdictional claims in published maps and institutional affiliations. 